\title{
Shaping Chromatin in the Nucleus: The Bricks and the Architects
}

\author{
David Sitbon, ${ }^{1,2}$ Katrina Podsypanina, ${ }^{1,2}$ Tejas Yadav, ${ }^{1,2}$ and Geneviève Almouzni ${ }^{1,2}$ \\ ${ }^{1}$ Institut Curie, PSL Research University, CNRS, UMR3664, Equipe Labellisée Ligue contre le \\ Cancer, Paris, France \\ ${ }^{2}$ Sorbonne Universités, UPMC Univ Paris 06, CNRS, UMR3664, Paris, France \\ Correspondence: genevieve.almouzni@curie.fr
}

\begin{abstract}
Chromatin organization in the nucleus provides a vast repertoire of information in addition to that encoded genetically. Understanding how this organization impacts genome stability and influences cell fate and tumorigenesis is an area of rapid progress. Considering the nucleosome, the fundamental unit of chromatin structure, the study of histone variants (the bricks) and their selective loading by histone chaperones (the architects) is particularly informative. Here, we report recent advances in understanding how relationships between histone variants and their chaperones contribute to tumorigenesis using cell lines and Xenopus development as model systems. In addition to their role in histone deposition, we also document interactions between histone chaperones and other chromatin factors that govern higher-order structure and control DNA metabolism. We highlight how a fine-tuned assembly line of bricks (H3.3 and CENP-A) and architects (HIRA, HJURP, and DAXX) is key in adaptation to developmental and pathological changes. An example of this conceptual advance is the exquisite sensitivity displayed by p53null tumor cells to modulation of HJURP, the histone chaperone for CENP-A (CenH3 variant). We discuss how these findings open avenues for novel therapeutic paradigms in cancer care.
\end{abstract}

Over the past decades, the study of chromatin structure and regulation has tremendously improved our understanding of overall nuclear organization, ranging from the basic repeating unit - the nucleosome core particle comprised of DNA wrapped around histones - up to beads-on-a-string and higher-order structures (Fig. 1A; Kornberg 1974; Olins and Olins 1974; Oudet et al. 1975; Laskey et al. 1978; McGhee and Felsenfeld 1980; Luger et al. 1997; Nora et al. 2012; Naumova et al. 2013). Together, these structures define the "epigenome" or specific chromatin landscapes that inform cell fate decisions and govern cell identity (Fig. 1B). Here, we refer to epigenetic features as the "structural adaptation of chromosomal regions to register, signal or perpetuate altered activity states" (Bird 2007). Unlike the embedded genetic code, epigenetic features of chromatin are plastic and can be reversed enabling genomic reprogramming (Gurdon 1962; Takahashi and Yamanaka 2006). Establishment, propagation, and maintenance of different layers in the hierarchical chromatin structure directly impinge upon gene function. At the most fundamental level, the nucleosome, histone variants provide a choice of distinct bricks in the construction of chromatin architecture. Accordingly, selection of histone variants and their handling by distinct histone chaperones (architects) contribute to the marking of specific genomic locations during various cell cycle phases (Fig. 2). A network of assembly lines involving chaperone-variant interactions regulates chromatin organization in various developmental stages and disease states (Gurard-Levin et al. 2014). Importantly, his- tone variants (Buschbeck and Hake 2017; Talbert and Henikoff 2017), histone-modifying enzymes (that catalyze distinct PTMs [posttranslational modifications] on histone variants) (Gurard-Levin and Almouzni 2014), and chromatin remodeling factors (Bowman and Poirier 2014; Swygert and Peterson 2014) are constituents of defined complexes that organize chromatin. Furthermore, these large, multicomponent complexes bring together transcription factors, chromatin-associated proteins, and DNA-modifying enzymes to interface with bricks and architects (De Koning et al. 2007). Hence, an ensemble is orchestrated in order to control gene regulation and cellular fate depending on temporal or spatial cues and a delicate balance of chromatin and transcription factor availability. Consequently, the stoichiometry of specific histone bricks, architects, and accessory factors is of paramount importance for chromatin regulation.

Notably, changes in histone variant and chaperone dosage are well known in the context of development. For example, in Xenopus, unusually high levels of Npm2 (nucleoplasmin 2), the first described histone chaperone (Laskey et al. 1978), are present in the oocyte and during early embryogenesis (Burglin et al. 1987; Litvin and King 1988). This elevated dosage of the architect $\mathrm{Npm} 2$ ensures storage of soluble histones $\mathrm{H} 2 \mathrm{~A}-\mathrm{H} 2 \mathrm{~B}$ contributing to chromatin assembly after fertilization during the rapid cell divisions in early development (Finn et al. 2012). In adult tissues, concentration of $\mathrm{Npm} 2$ decreases in parallel with the lower rate of cell division. During early development, a switch from storage to rapid deposition of histones

(C) 2017 Sitbon et al. This article is distributed under the terms of the Creative Commons Attribution-NonCommercial License, which permits reuse and redistribution, except for commercial purposes, provided that the original author and source are credited. 
A

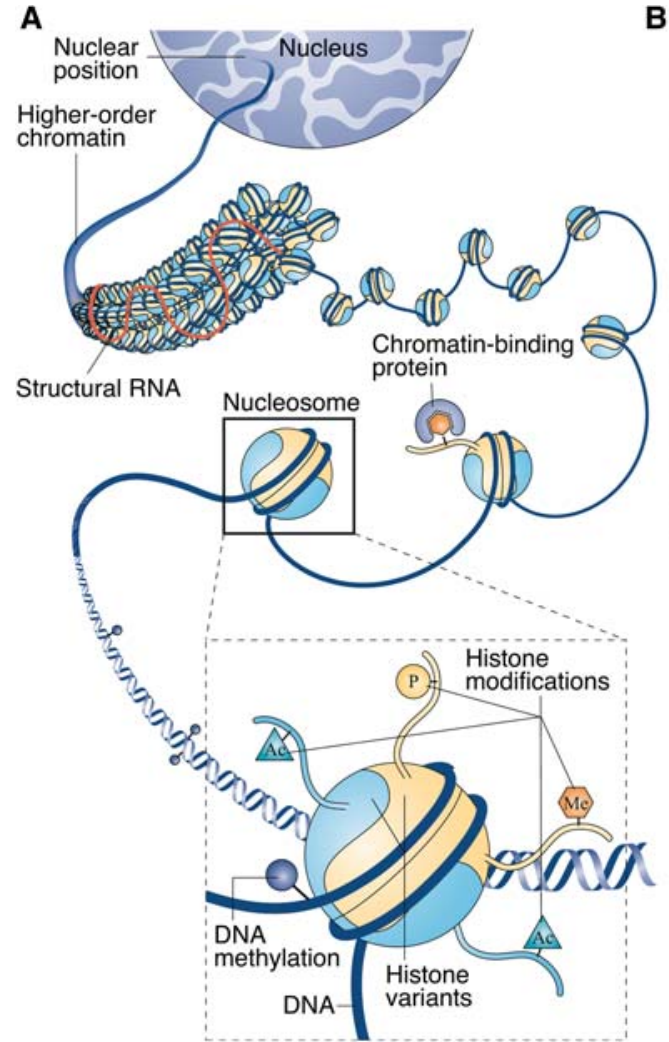

B
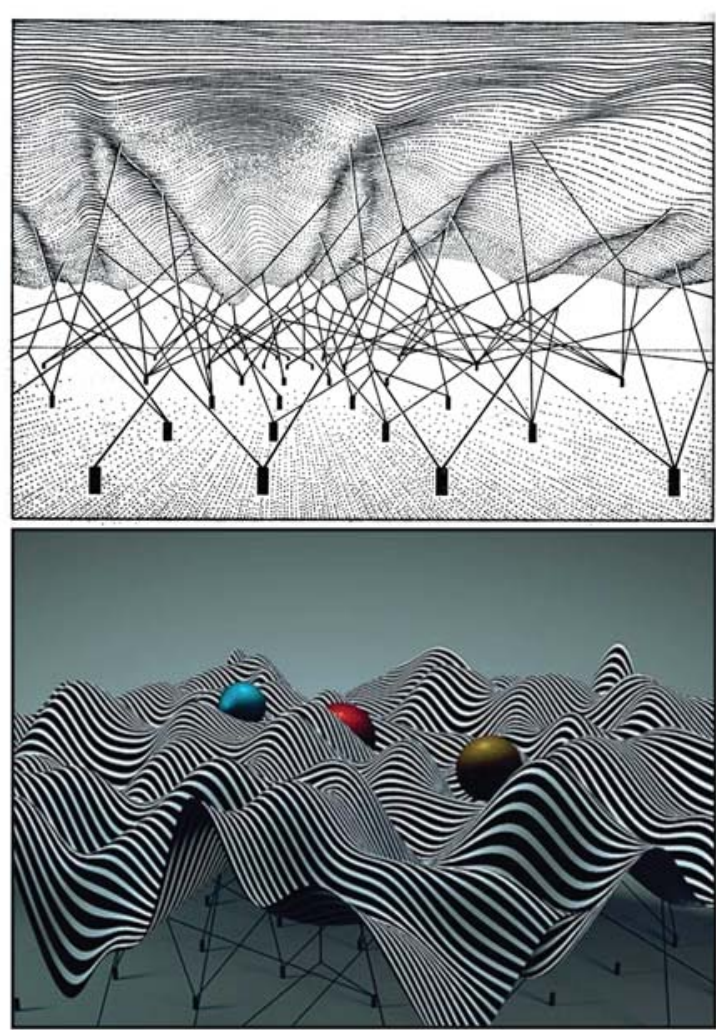

Figure 1. Epigenetic components of chromatin architecture and a complex network of interactions underlying cell fate determination. (A) Numerous epigenetic factors help organize chromatin in the 4D nucleus: along with the linker histone H1, DNA wrapped around one $(\mathrm{H} 3-\mathrm{H} 4)_{2}$ tetramer capped by two H2A-H2B dimers forms the nucleosome- the fundamental repeating unit of chromatin. DNA can be methylated and histones can be posttranslationally modified (e.g., by methylation [Me], acetylation [Ac], and phosphorylation [P]). Chromatin-binding proteins such as methyl- or histone-recognizing factors read the information encoded by these covalent marks. The presence of histone variants adds further complexity. Arrays of nucleosomes fold into higher-order chromatin structures, potentially guided by noncoding RNA. The nuclear localization of a given chromosomal domain represents an additional level of regulatory information. (B) View from below of the historical Waddington landscape (top). Pegs represent genes and the strings represent a complex system of genetic interaction that determines cell fate. The epigenetic landscape is shaped by the strings, which are ultimately anchored to the genes. (Bottom) A modern re-interpretation of the Waddington landscape. The valleys represent ongoing decision events in cells (represented by colored beads) on their path to a final cell fate. (A, Adapted, with permission, from Probst et al. 2009; $B$, top, reprinted, with permission, from Waddington 1957; bottom, reproduced, with permission, from Paul L. Harrison and the Epigenesys Network.)

is controlled by both the level of chaperones and the amount of soluble histones. Early studies showed that pre-MBT (midblastula transition) transcriptional repression could be alleviated by titration with exogenous DNA (Newport and Kirschner 1982). This is in line with the importance of histone concentration as depletion of $\mathrm{H} 3$ protein results in premature cell cycle elongation in the embryo, whereas excess H3-H4 maintains shorter cell cycles after MBT (Amodeo et al. 2015). Notably, interfering with chromatin assembly pathways leads to aberrant development in Xenopus embryos (Quivy et al. 2001; Ray-Gallet et al. 2002; Szenker et al. 2012). In somatic mammalian cells, the soluble pool of histones is regulated by histone chaperones NASP (nuclear autoantigenic sperm protein) (Cook et al. 2011) and Asfl (antisilencing factor 1) (Groth et al. 2005) that act as a reservoir for excess H3-H4. These chaperones mitigate fluctuations in supply and demand of histones upon replication stress, when the replication fork arrests and newly synthesized histones cannot be loaded onto new DNA. Moreover, his- tone management is particularly critical at telomeres where down-regulation of Asfl activates the ALT (alternative lengthening of telomeres) pathway, thereby compromising genome integrity (O'Sullivan and Almouzni 2014). The importance of histone variant handling is further underscored in mice defective for replication-coupled histone chaperone CAF-1 (chromatin assembly factor 1), composed of p150, p60, p48 subunits in mammals (Houlard et al. 2006). CAF-1 mutant animals display heterochromatin disorganization and arrest during early embryonic development. Interestingly, fine-tuning levels of CAF-1 influence somatic cell identity, allowing efficient production of induced pluripotent stem cells (Cheloufi et al. 2015; Ishiuchi et al. 2015; Yang et al. 2015). The above examples highlight the inherently plastic nature of the chaperone-variant network during growth and development, an aspect that needs to be further explored in various contexts and cell lineages.

The study of diseases provides another case where the role of variants and chaperones is at stake. Indeed, identi- 


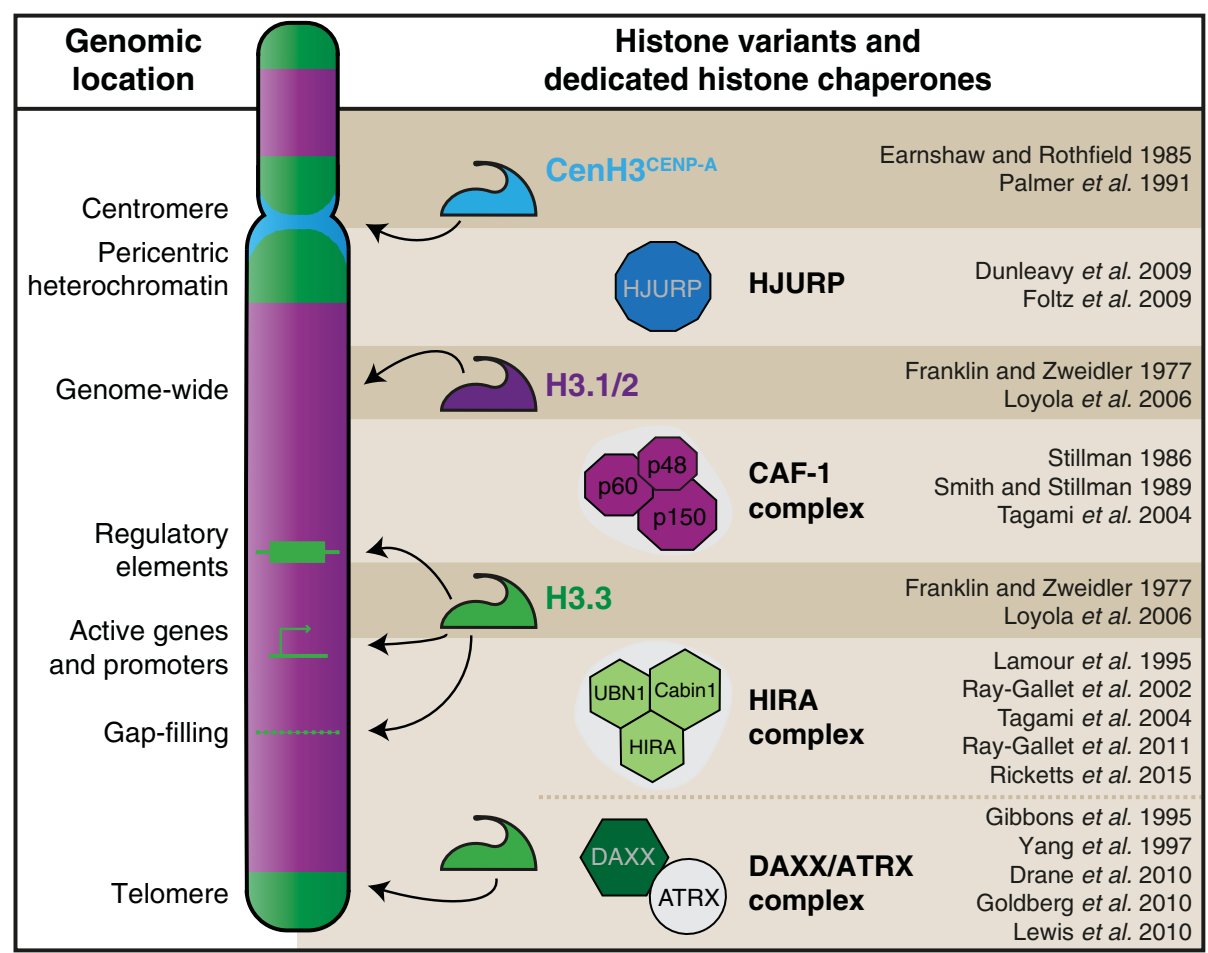

Figure 2. Histone variants (bricks) and their associated histone chaperones (architects) mark specific chromosomal regions. Among H3 variants in humans, at least four are handled by specific histone chaperones during particular cell cycle stages: new CENP-A, the centromeric variant, is incorporated at centromeres by HJURP during late mitosis-early $\mathrm{G}_{1} ; \mathrm{H} 3.1 / 2$, the replicative variants, are incorporated genome-wide during DNA synthesis by CAF-1 complex; H3.3, the replacement form, is placed throughout the cell cycle at regulatory elements, gene bodies by the HIRA complex, and at telomeres and pericentric heterochromatin by the DAXX/ATRX complex.

fication of $\mathrm{H} 3$ variant mutations in very aggressive pediatric tumors exemplifies a major role for histone variants in cancer (Schwartzentruber et al. 2012; Wu et al. 2012; Lewis et al. 2013). Furthermore, a variety of tumors carry mutations in the H3.3 histone chaperone DAXX (death-domain associated protein 6 )/ATRX ( $\alpha$-thalassemia mental retardation syndrome X-linked) complex (Heaphy et al. 2011; Jiao et al. 2011; Schwartzentruber et al. 2012). How distinct mutations alter the chaperone-variant balance and contribute to tumorigenesis is an active area of research. Interestingly, at the transcriptional level, cancers also often display alterations in the expression of histone regulators including key histone variants and chaperones (Montes de Oca et al. 2015; Gurard-Levin et al. 2016). For example, a series of cancer types show up-regulation of Asflb, one of the two human paralogs of the Asfl chaperone (Corpet et al. 2011). Notably, overexpression of CENP-A, the centromere-specific histone variant (Tomonaga et al. 2003; Amato et al. 2009), or its cognate histone chaperone HJURP (Holliday junction recognition protein) (Kato et al. 2007; Montes de Oca et al.2015) is a hallmark of tumor progression and poor prognosis. Here, we summarize recent work suggesting that therapies targeted against specific histone chaperones and their "client" variants represent a promising opportunity for improved cancer care. In addition, we highlight how dynamics of CENP-A in cancer (Lacoste et al. 2014; Filipescu et al. 2017) and H3.3 in development (Szenker et al. 2012) can open new avenues for fundamental and translational research in the future.

\section{H3 VARIANT DYNAMICS: VARIATIONS ON A THEME IN THE 4D NUCLEUS}

Histone variants are forms of the four core histones ( $\mathrm{H} 3$, $\mathrm{H} 4, \mathrm{H} 2 \mathrm{~A}$, and $\mathrm{H} 2 \mathrm{~B}$ ), originally characterized based on migration properties using Triton acid urea gel electrophoresis (Franklin and Zweidler 1977). For H3 histones, this technique enabled the distinction of two major categories -namely, the replicative and replacement variants. In humans, the two closely related replicative variants $\mathrm{H} 3.1$ and H3.2 - later referred to as H3.1/2 - show a peak of expression in $\mathrm{S}$ phase and are incorporated into chromatin via the DSC (DNA synthesis-coupled) pathway during replication (Stillman 1986; Smith and Stillman 1989; Groth et al. 2007) or DNA repair (Gaillard et al. 1996; Polo et al. 2006). The replacement variant H3.3, incorporated via the DSI (DNA synthesis-independent) pathway (RayGallet et al. 2002), is expressed throughout all cell cycle phases, including quiescence, and is associated with transcription (Ahmad and Henikoff 2002) and major rearrangements of the sperm chromatin during fertilization (Katagiri and Ohsumi 1994; Ahmad and Henikoff 2002; Loppin et al. 2005; Torres-Padilla et al. 2006; Bonnefoy et al. 2007; Santenard et al. 2010; Orsi et al. 2013). Finally, the most divergent $\mathrm{H} 3$ variant $\mathrm{CenH} 3$ (centromeric histone 3), called CENP-A (histone H3-like centromeric protein A) in humans (Earnshaw and Rothfield 1985; Palmer et al. 1991), is specifically associated with centromeric regions (Muller and Almouzni 2017). In mammals, 
CENP-A shows a peak of expression during the $G_{2} / M$ phases, and new CENP-A is specifically incorporated during late mitosis-early $\mathrm{G}_{1}$ phase (Shelby et al. 2000; Jansen et al. 2007). In humans, eight H3 variants have been identified to date (Maze et al. 2014); the existence of corresponding homologs in other organisms highlights remarkable conservation across species (Waterborg 2012). A detailed analysis of histone variant deposition and maintenance by histone chaperones during the cell cycle (both at specific chromosomal territories and in different cell types) is central to our understanding of local nucleosome organization and genome-wide chromatin states.

A particular group of histone chaperones, which we call "dedicated" architects, selectively regulate histone variant availability and placement across time and space in the nucleus (Fig. 2; Gurard-Levin et al. 2014; Hammond et al. 2017). As mentioned above, CAF-1 is involved in chromatin assembly in the DSC pathway (Stillman 1986; Smith and Stillman 1989) shown by the presence of CAF1 in complex with the replicative variant (Tagami et al. 2004). Similarly, isolation of the H3.3 complex identified two distinct histone chaperone complexes that work in combination to orchestrate incorporation of the replacement histone variant H3.3. On one hand, the HIRA (histone cell cycle regulator A) complex-composed of HIRA and at least two other subunits, Cabin1 (calcineurin-binding protein 1) and UBN1 (ubinuclein 1) (Ricketts and Marmorstein 2017), and possibly also UBN2 (ubinuclein 2) (Banumathy et al. 2009)_deposits H3.3 at gene bodies, promoters, and regulatory elements (Lamour et al. 1995; Ray-Gallet et al. 2002; Tagami et al. 2004). On the other hand, the DAXX/ATRX complex contributes to the $\mathrm{H} 3.3$ presence at peri-centromeric regions and telomeres (Gibbons et al. 1995; Yang et al. 1997; Drane et al. 2010; Goldberg et al. 2010; Lewis et al. 2010). Finally, we used a similar strategy for isolation of the most divergent variant, CENP-A, in a soluble predeposition complex. This led to the identification of the chaperone HJURP (Dunleavy et al. 2009; Foltz et al. 2009; Shuaib et al. 2010), as being responsible for the specific loading of CENP-A at centromeres in late mitosis-early $\mathrm{G}_{1}$ phase.

While dedicated histone chaperones can ensure the delivery of specific histones at the right time and place, other chaperones do not show such selectivity. Yet, such "casual" chaperones play critical functions in histone supply and demand during DNA replication and genotoxic events. For example, Asfl acts upstream of dedicated histone chaperones, handling old and newly synthesized soluble core histones (Tyler et al. 1999; Munakata et al. 2000; Sharp et al. 2001; Mello et al. 2002). Asf1 is also involved in nucleosome assembly during temporally constrained processes such as DNA replication (Groth et al. 2005, 2007). Additionally, Asf1 influences chromosome stability at distinct landmarks, such as chromosome ends, by regulating telomere length maintenance (O'Sullivan and Almouzni 2014). NASP (nuclear autoantigenic sperm protein) acts as an emergency reservoir of soluble histones (Welch et al. 1990; Richardson et al. 2000), and MCM2 (DNA replication licensing factor, a component of the
DNA helicase), newly identified as a histone chaperone, coordinates parental histone recycling at the replisome (Clement and Almouzni 2015; Huang et al. 2015; Richet et al. 2015). Importantly, casual chaperones display remarkable versatility as they can potentially interact with different histone variants. In summary, we propose that there are histone chaperones that care more about "who" (which specific histone variant), others that care about "when and why" (DNA replication, transcription, or developmental fate changes), and yet others that remain "multifunctional," in some cases even indiscriminatingly nonselective. Within such a multipartner network, it appears that the choice between these alternatives is dependent on the nuclear availability and relative abundance of specific histone variants and chaperone molecules.

\section{A CASE OF CELLULAR ADAPTABILITY TO CHANGES IN DOSAGE}

Although previous studies emphasize selective partnerships, perturbations to histone variant and chaperone interactions exist in physiological and disease contexts (Buschbeck and Hake 2017). Recent studies on centromeric chromatin assembly provide a striking example of polyvalent partner switching as a result of altered histone variant dosage (Lacoste et al. 2014; Shrestha et al. 2017). In healthy human, mouse, and most other eukaryotic cells, CENP-A marks the centromeres (Fig. 3A; Fukagawa and Earnshaw 2014; McKinley and Cheeseman 2016). Indeed, centromeric histone variant CENP-A is an integral epigenetic determinant of centromere identity and genome maintenance (Allshire and Karpen 2008). Loss of CENP-A gives rise to defects in mitosis and leads to senescence (Maehara et al. 2010). Yet, the proportion of CENP-A-containing nucleosomes at the centromere is low, with current estimates of only $2 \%-4 \%$ of total $\alpha$-satellite DNAwrapped around CENP-A-containing nucleosomes in cultured diploid human cells (Bodor et al. 2013; Nechemia-Arbely et al. 2017). Thus, even at a steady state, total CENP-A levels in proliferating RPE (retinal pigment epithelium) cells are almost 100 times higher than the relative amount associated with centromeric DNA (Bodor et al. 2014). One hypothesis proposes that surplus CENP-A safeguards against chromosome loss during random redistribution of old and new CENP-A following cell division. Altogether, these findings point toward the central role of HJURP in de novo CENP-A deposition and, consequently, in centromere establishment, maintenance, and propagation.

Recent experimentation has helped to uncover interesting changes associated with a pathological excess of either histone variants or chaperones or both in cases of co-regulated expression. Increased levels of CENP-A are commonly reported in a range of aggressive cancers (Ma et al. 2003; Tomonaga et al. 2003; Li et al. 2011; Qiu et al. 2013; Gu et al. 2014; Benito et al. 2015; Sun et al. 2016). The excess CENP-A can be incorporated both at the centromere and also in the chromosome arms (Fig. $3 \mathrm{~B})$. We have generated a model of oncogene-transformed MEFs (mouse embryonic fibroblasts) that recapitulates the 
A

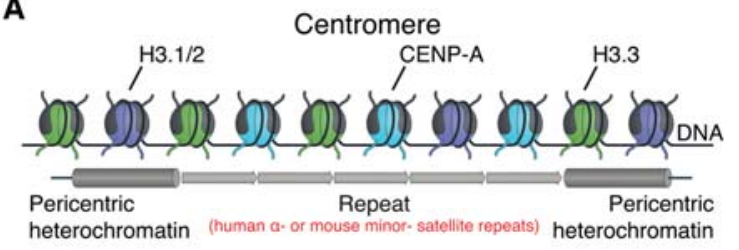

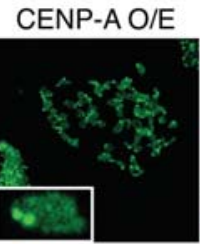

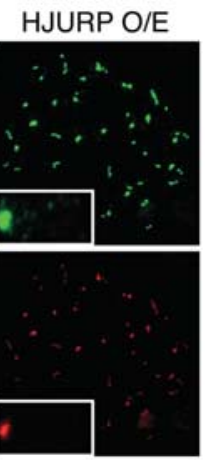

p53-null MEF

C
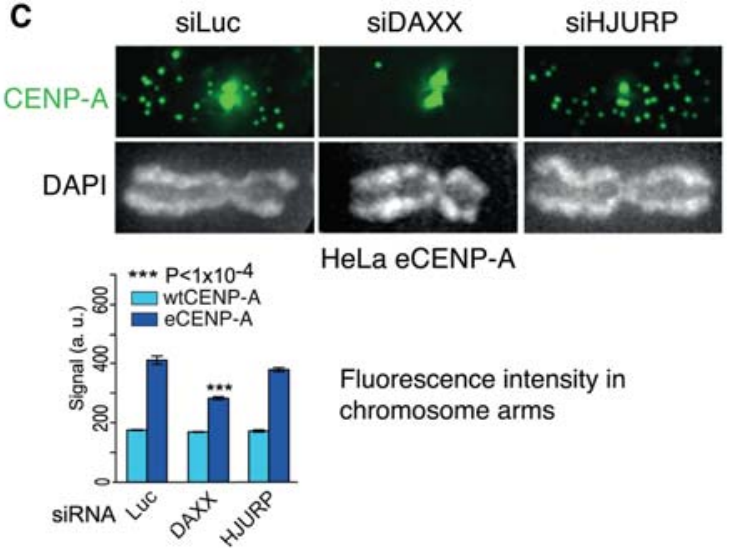

Fluorescence intensity in chromosome arms

Figure 3. DAXX mediates ectopic CENP-A deposition in chromosome arms. (A) Schematic representation of centromeric chromatin. Centromeres comprise CENP-A nucleosomes interspersed with H3.1/2 and H3.3 nucleosomes. Centromeric chromatin contains minor- (in mice) and $\alpha$ - (in humans) satellite repeats flanked by pericentric heterochromatin. $(B)$ DNA FISH on metaphase spreads of p53-null mouse embryonic fibroblasts (MEFs) transduced with the indicated retroviral construct. Cells were stained with an antibody against CENP-A and LNA FISH (fluorescence in situ hybridization) probes for minor satellites (site of centromeric CENP-A deposition). Insets show individual magnified chromosomes. Overexpression (O/E) of CENPA, but not HJURP, leads to ectopic deposition of CENP-A on chromosome arms. $(C)$ Fluorescent microscopy visualization of CENP-A after treatment with the indicated siRNA in a human cell line overexpressing CENP-A (HeLa eCENP-A). Depletion of histone chaperone DAXX, but not HJURP, rescues the ectopic CENP-A deposition phenotype. Histogram representing the fluorescence of CENP-A present in chromosome arms of metaphase spreads from two cell lines (wild-type, wtCENP-A and overexpression, eCENP-A) treated with the indicated siRNA. $P$ values represent pairwise comparison of siLuc (control), and all other siRNAs tested with the same cell line with a Mann-Whitney $U$-test. ( $A$, Adapted, with permission, from Muller and Almouzni 2017; $B$, adapted, with permission from Filipescu et al. 2017; $C$, adapted, with permission, from Lacoste et al. 2014.)

increase in CENP-A and HJURP levels (Filipescu et al. 2017). Notably, in MEFs, altering the dose of the brick or its architect does not necessarily lead to the same outcome. Indeed, overexpressing HJURP in cultured cells leads to increased CENP-A deposition at the centromere, but not in the arms, in line with its specific role in targeting CENP-A to the centromere. Conversely, experimentally induced or cancer-associated surplus CENP-A enables ectopic deposition of additional CENP-A molecules at the chromosome arms. Presumably, this effect is observed because the cognate chaperone HJURP, required for the specific targeting, is limiting. Our data show that another multifaceted histone chaperone DAXX (part of the DAXX/ATRX complex) is involved in the ectopic deposition in the arms (Fig. 3C; Lacoste et al. 2014). Arguably, chaperone-variant polyvalency in centromere assembly indicates flexibility in the interaction modules of various architects and bricks. Partner switching, wherein histone chaperones promiscuously interface with additional histone variants, contributes to a new dimension of adaptation to shifting physiological needs and nucleic acid transactions. Disease scenarios represent one such context wherein inherently plastic histone variant-chaperone relationships become critical in the face of pathological challenges to growth and survival.

\section{ALTERED DOSAGE OF ARCHITECTS AND BRICKS POTENTIATES TUMORIGENESIS: FROM MOUSE MODELS TO HUMAN PATHOLOGY}

Substantial changes in the levels of molecular components (including chromatin regulators and transcription factors) have been characterized in several genetic diseases including cancer (Montes de Oca et al. 2015; GurardLevin et al. 2016). Epigenetic factors may be altered as a consequence of cancer-causing mutations, without themselves being mutated (Fig. 4A). We analyzed TCGA data to show that a genetic defect in the tumor suppressor p53 selectively up-regulates centromeric histone variant CENP-A and its chaperone HJURP in cancers of different origins (Fig. 4B). In a reporter system, p53 can associate at the promoters of CENP-A and HJURP, as part of the E2FDREAM repressive complex (Filipescu et al. 2017). This finding indicates that increased CENP-A and HJURP levels are linked to loss of the transcriptional function of p53 in cancer cells. Interestingly, CENP-A and HJURP are overexpressed not only in cancers with p53-inactivating genetic lesions, but also in a subset of tumors with gainof-function mutations in p53 (Filipescu et al. 2017). To determine whether this aspect of p53-mediated up-regulation involves other transcription factors, such as FoxM1 (a p53-partner), it will be necessary to extend experiments to new mutant mouse models (Barsotti and Prives 2009; Bieging et al. 2014). Importantly, although CENP-A and HJURP levels are high in p53-deficient transformed cells, this elevation cannot be merely attributed to hyperproliferation (Filipescu et al. 2017). To determine if an increased dose of a histone variant or its chaperone could 
A
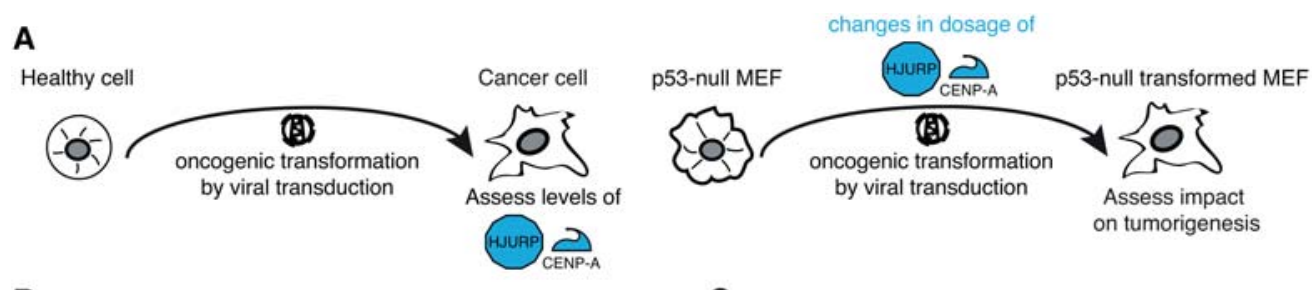

B

TCGA data: All cancers

C

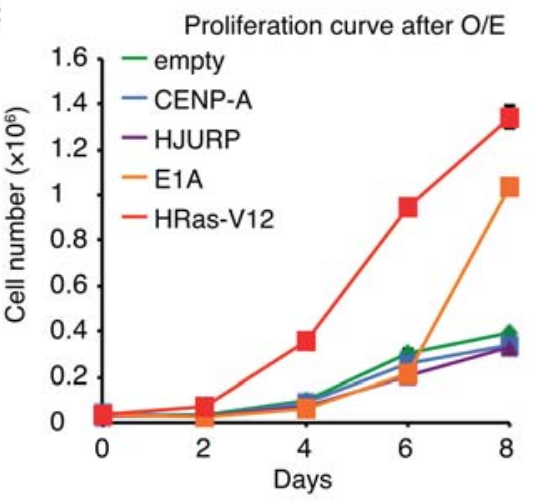

D
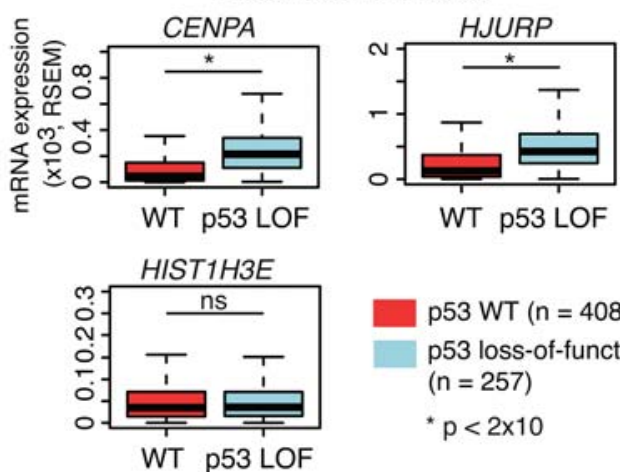

p53 WT $(n=4083)$

p53 loss-of-function

$(n=257)$

* $p<2 \times 10$

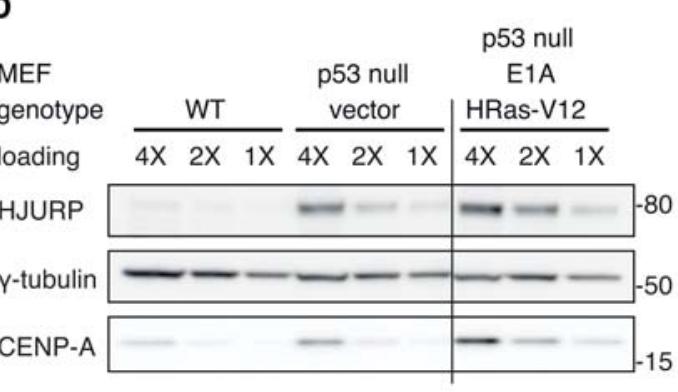

E

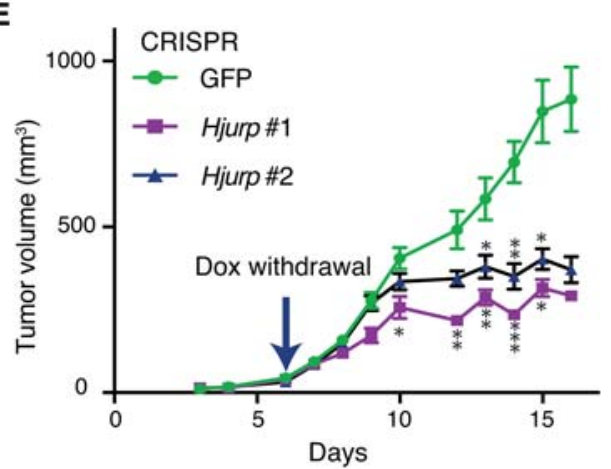

Figure 4. Cancer cells display addiction to chromatin architect HJURP. $(A)$ Key chromatin factors, including important bricks and architects, display variations in expression during tumorigenesis. HJURP and CENP-A levels were assessed in experimentally transformed cells and in human cancer cells. Then, their levels were modified in cultured cells and in tumors to assess effects on tumorigenesis. $(B)$ Gene expression levels of CENP-A and HJURP are higher in cancers with defective p53. Box plot comparisons of relative expression (mRNA) of genes coding for CENP-A (CENPA), HJURP (HJURP), and H3.1 (HIST1H3E) from all cancers (28 cancer types), classified according to p53 status (TCGA provisional data). Tumors are either wild type for TP53 $(n=4083)$ or p53 loss of function (LOF) $(n=257)$. Significance was computed using Wilcoxon rank sum tests. $(C)$ HJURP or CENP-A overexpression alone does not transform p53-null MEFs. Proliferation curve of p53-null MEFs transduced with the indicated retroviral construct. The graph displays the quantified cell number \pm SEM of triplicates. $(D)$ HJURP and CENP-A are overexpressed in p53-null wild-type and transformed MEFs. Western blot of HJURP and CENP-A levels in RIPA-soluble extracts from MEFs transduced with empty vector or sequentially with E1A and HRas-V12. (E) Conditional depletion of exogenous HJURP stops the growth of established tumors lacking endogenous HJURP. Allograft assay measuring tumor growth following HJURP knockout over time. p53-null HRas-V12 MEFs were generated with an inducible CRISPR-resistant HJURP transgene maintained in the presence of doxycycline. Doxycycline was withdrawn on day 6 after injection (Hjurp switched off) and allograft tumor volume was measured over time. Data represent mean tumor volume \pm SEM. * $P<0.05$; **, $P<0.005$; ***, $P<0.0005$, $t$-test. (Adapted, with permission, from Filipescu et al. 2017.)

drive transformation, we overproduced the two factors individually in mouse cells. These experiments proved that the inducible overexpression of CENP-A and HJURP do not act as "drivers" of transformation in a p53-null background, unlike a second hit with a viral oncogene E1A or a mutant form of HRas (Fig. 4C).

Until recently, the specific role of centromeric variantchaperone partnerships has remained largely unexplored in cells lacking a proficient p53 checkpoint pathway. In human and mouse cells, CENP-A and HJURP levels are co-regulated through a dual control mechanism involving both transcriptional and posttranslational modes. Early studies had found that loss of either CENP-A or HJURP leads to growth arrest with features of senescence and p53 pathway activation (Maehara et al. 2010; Heo et al. 2013; Valente et al. 2013). As mentioned above, in p53-defective cells, there is a burst of expression of both centromeric factors CENP-A and HJURP (Fig. 4D). Instead of undergoing growth arrest, both mouse and human p53-deficient cells undergo rapid apoptosis upon removal of HJURP (Filipescu et al. 2017). Remarkably, in a p53-deficient background, severely reduced growth of established tumors occurs upon conditional depletion of HJURP (using a doxycycline-dependent system) (Fig. 4E). Thus, in the 
absence of p53-dependent checkpoint activation, cells develop an "epigenetic" addiction to HJURP, likely because of its important role in CENP-A loading at centromere. This is the first reported example of a histone chaperone being necessary to support tumor growth and kinetics of tumor progression. However, epigenetic addiction is also a part of other cancer phenotypes, including evidence for acquired dependence on histone-modifying enzyme, MLL, in tumor cells with gain-of-function mutations in p53 (Zhu et al. 2015). Thus, the case of cancers addicted to high levels of epigenetic factors reflects a wider phenomenon of context-specific requirement for chromatin organization. Realizing the full promise of targeting the epigenome (Gurard-Levin et al. 2016; Morel et al. 2017) and its components in cancer necessitates indepth exploration of chaperone-variant imbalance and downstream consequences. Patient-derived samples and animal models in conjunction with the latest genome editing tools (such as CRISPR-Cas9) and rapid protein-degradation methods (like auxin-inducible or photo-activated degrons) will be instrumental in the determination of relevant drug targets that serve as the Achilles' heel for epigenetically addicted tumors.

\section{A CENTRAL ROLE FOR HISTONE VARIANTS IN DEVELOPMENT}

Given the high degree of sequence similarity between histone variants, contextual differences raise the issue of variant interchangeability and redundancy (Waterborg 2012). Indeed, mammalian replicative histone variants H3.1 and H3.2 only differ from the replacement form H3.3 by five and four residues, respectively. Despite these seemingly minor variations in amino acid composition, replicative and replacement histone variants cannot directly substitute for each other without causing deleterious effects in mammals (Couldrey et al. 1999; Bush et al. 2013; Tang et al. 2015). Both H3.1 and H3.2 variants are used during DNA synthesis to provide a full complement of histones necessary to assemble newly replicated chromatin (MacAlpine and Almouzni 2013). Besides contributing to the bulk of new H3.1 and H3.2 histones in S phase, the unique roles of replicative H3 variants have remained largely uncharacterized. Intriguingly, in Arabidopsis thaliana, the H3.1 variant mediates the restoration of the transcriptional repressive mark H3K27me3 during DNA replication (Jacob et al. 2014; Jiang and Berger 2017). This specificity observed in plants merits careful examination in mammals to uncover similar dedicated functions.

The replacement variant H3.3, which can be incorporated at any time during the cell cycle, has been linked to many critical cell processes ranging from transcription and DNA repair to reprogramming (Ahmad and Henikoff 2002; Schwartz and Ahmad 2005; $\mathrm{Ng}$ and Gurdon 2008; Jullien et al. 2012; Adam et al. 2013). However, it has been difficult to evaluate whether the identity of H3.3 variant or its specific mode of incorporation is crucial for these processes. Evolutionary analyses can help shed light on distinct and universal roles of $\mathrm{H} 3.3$ variants. Interestingly, yeast possesses a single form of noncentromeric histone $\mathrm{H} 3$, closely related to the mammalian $\mathrm{H} 3.3$ variant and capable of performing both replicative and replacement functions (Dion et al. 2007; Jamai et al. 2007; Rufiange et al. 2007). In contrast, the need for specific histone variants $\mathrm{H} 3.1$ and $\mathrm{H} 3.3$ is observed in A. thaliana (Jacob et al. 2014; Jiang and Berger 2017). Here, we have compiled phenotypes linked to alteration of H3.3 and its associated chaperones observed across different species (Table 1). In most multicellular eukaryotes, different developmental stages are sensitive to removal of key chromatin players. Thus, each of these developmental time periods represents critical windows for interrogating context-dependent cellular functions of histone variants. In A. thaliana, complete loss of H3.3 leads to embryonic lethality and partial sterility due to defective male gametogenesis (Wollmann et al. 2017). Albeit replicative histone forms in Drosophila melanogaster can compensate for the absence of H3.3 variant in somatic tissues, both male and female flies are sterile (Hodl and Basler 2009; Sakai et al. 2009). A possible explanation for H3.3-related sterility is the lack of a sufficient pool of maternal H3.3 to help in replacing protamines in the sperm after fertilization. Unlike flies, worms remain viable and fertile despite a complete loss of the H3.3 variant (Piazzesi et al. 2016). Indeed, Caenorhabditis elegans lacking H3.3 display only mild phenotypes such as "bagging" (eggs hatching inside the adult body) and heightened sensitivity to stress. In vertebrate models, such as Mus musculus, deletion of one of the two copies of H3.3 leads not only to sterility but also to developmental defects (Couldrey et al. 1999; Bush et al. 2013; Tang et al. 2015). Notably, point mutations in human H3 variants, such as K27M and G34R/V (Schwartzentruber et al. 2012; Wu et al. 2012), or their associated chaperones (Heaphy et al. 2011; Jiao et al. 2011) are linked to aggressive pediatric glioblastoma. The question remains whether individual histone $\mathrm{H} 3$ residues are functional during development (loss of function) or provide adaptive advantages following (gain-of-function) mutation in cancer cells. Taken together, these findings underline the role of specific bricks and architects during cell fate determination and metazoan development. Finally, the striking case of brain tumors occurring in children highlights the important link between developmental contexts and cancer.

In vertebrates, research on chromatin assembly was pioneered in Xenopus laevis (Laskey et al. 1977) enabling further characterization of distinct nucleosome deposition pathways (Almouzni and Mechali 1988) and the key roles of histones chaperones (Quivy et al. 2001; Ray-Gallet et al. 2002). The high yield of eggs supplies a large quantity of material available for experimentation both in vitro and in vivo (Gurdon 1976). This widely used model provides several salient advantages for the study of chromatin (Almouzni et al. 1990). Given the recurrent sterility phenotype in many species, Xenopus offers a convenient setting to investigate other functions of H3.3 as sperm chromatin retains $\mathrm{H} 3.3-\mathrm{H} 4$ dimers instead of protamines (Katagiri and Ohsumi 1994). In addition, the presence of a 
Table 1. Alteration in histone variant H3.3 and associated-chaperones across species

\begin{tabular}{|c|c|c|c|c|c|c|}
\hline \multirow{2}{*}{ 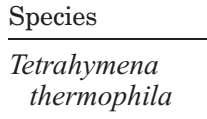 } & \multicolumn{2}{|c|}{ Strategy of H3.3 alteration } & \multirow{2}{*}{$\begin{array}{l}\text { Associated phenotype(s) } \\
\text { H3.3 KO is viable but leads to } \\
\text { sterility }\end{array}$} & \multicolumn{2}{|c|}{ Strategy of chaperone alteration } & \multirow{2}{*}{$\begin{array}{l}\text { Associated phenotype(s) } \\
\text { No mutant alleles tested }\end{array}$} \\
\hline & $\begin{array}{l}\text { Deletion of the only H3.3- } \\
\text { encoding gene (HHT3) }\end{array}$ & Cui et al. 2006 & & $\begin{array}{l}\text { TTHERM_00046490 annotated as } \\
\text { HirA homolog }\end{array}$ & Miao et al. 2009 & \\
\hline & & & & No reported homolog of DAXX & Lewis et al. 2010 & No mutant alleles tested \\
\hline $\begin{array}{l}\text { Arabidopsis } \\
\text { thaliana }\end{array}$ & $\begin{array}{l}\text { Deletion of two histone } \mathrm{H} 3.3 \\
\text { genes (HTR4, HTR } 8) \\
\text { artificial mRNAs target third } \\
\text { copy (HTR5) }\end{array}$ & Wollmann et al. 2017 & $\begin{array}{l}\mathrm{H} 3.3 \mathrm{KD} \text { impairs male } \\
\text { gametogenesis; } \mathrm{H} 3.3 \mathrm{KO} \text { is } \\
\text { lethal }\end{array}$ & $\begin{array}{l}\text { T-DNA insertional mutant alleles } \\
(H I R A, U B N 1, U B N 2, C A B I N 1) \\
\text { and artificial mRNA against HIRA } \\
\text { No reported homolog of DAXX }\end{array}$ & $\begin{array}{l}\text { Duc et al. } 2015 \\
\text { Wollmann et al. } 2012\end{array}$ & $\begin{array}{l}\text { Individual mutants are viable; } \\
\text { HIRA KO and KD show } \\
\text { reduced fertility } \\
\text { No mutant alleles tested }\end{array}$ \\
\hline \multirow[t]{2}{*}{$\begin{array}{l}\text { Saccharomyces } \\
\text { cerevisiae }\end{array}$} & $\begin{array}{l}\text { Deletion of both histone } \mathrm{H} 3 \\
\text { genes }(H H T 1, H H T 2)\end{array}$ & Jamai et al. 2007 & $\begin{array}{l}\mathrm{H} 3 \text { (ancestral } \mathrm{H} 3.3 \text {-like } \\
\text { histone) KO is lethal }\end{array}$ & $\begin{array}{r}\text { Deletion of individual HIR complex } \\
\text { genes (HIR1, HIR 2, HIR } 3, H P C 2 \text { ) }\end{array}$ & $\begin{array}{l}\text { Osley 1991; Kaufman } \\
\text { et al. 1998; Qian et al. } \\
1998\end{array}$ & $\begin{array}{l}\text { Individual and double KOs are } \\
\text { viable but result in } \\
\text { derepression of histone } \\
\text { genes outside of late G1/S } \\
\text { phase }\end{array}$ \\
\hline & $\begin{array}{l}\text { Galactose-inducible } H H T 2 \\
\text { allele; remaining H3 copy } \\
(H H T 1) \text { is deleted }\end{array}$ & Gossett and Lieb 2012 & & No reported homolog of DAXX & Lewis et al. 2010 & No mutant alleles tested \\
\hline \multirow[t]{2}{*}{$\begin{array}{l}\text { Caenorhabditis } \\
\text { elegans }\end{array}$} & $\begin{array}{l}\text { Loss-of-function alleles of } \\
\text { H3.3-encoding genes }\end{array}$ & Piazzesi et al. 2016 & $\begin{array}{l}\mathrm{H} 3.3 \mathrm{KO} \text { is viable but leads to } \\
\text { bagging phenotype (eggs }\end{array}$ & $\begin{array}{l}\text { K10D2.1 or ceHILP annotated as } \\
\text { HIRA homolog }\end{array}$ & Wilming et al. 1997 & No mutant alleles tested \\
\hline & $(H I S 72, H I S 71)$ & & $\begin{array}{l}\text { hatching within animal) and } \\
\text { stress sensitivity }\end{array}$ & No reported homolog of DAXX & Lewis et al. 2010 & No mutant alleles tested \\
\hline \multirow[t]{2}{*}{$\begin{array}{l}\text { Drosophila } \\
\quad \text { melanogaster }\end{array}$} & $\begin{array}{l}\text { Deletion of the two histone } \\
\text { H3.3-encoding genes } \\
\text { (His3.3A,His3.3B) }\end{array}$ & $\begin{array}{l}\text { Sakai et al. 2009; Hodl } \\
\text { and Basler } 2009\end{array}$ & $\begin{array}{l}\mathrm{H} 3.3 \mathrm{KO} \text { is viable but leads to } \\
\text { sterility }\end{array}$ & $\begin{array}{l}\text { Loss of function Hira or UBN1 } \\
\text { allele(s) }\end{array}$ & $\begin{array}{l}\text { Loppin et al. 2005; } \\
\text { Bonnefoy et al. } 2007\end{array}$ & $\begin{array}{l}\text { HIRA KO is viable but } \\
\text { females are sterile; HIRA } \\
\text { deposits H3.3 in the } \\
\text { decondensed sperm } \\
\text { pronucleus }\end{array}$ \\
\hline & & & & $\begin{array}{l}\text { Loss-of-function allele of DAXX- } \\
\text { encoding } d l p \text { gene }\end{array}$ & $\begin{array}{l}\text { Fromental-Ramain et al. } \\
2017\end{array}$ & DAXX KO is viable \\
\hline \multirow[t]{2}{*}{ Xenopus laevis } & $\begin{array}{l}\text { Morpholino targeting H3.3- } \\
\text { encoding } h 3 f 3 a \text { mRNA }\end{array}$ & Szenker et al. 2012 & $\begin{array}{l}\mathrm{H} 3.3 \mathrm{KD} \text { leads to gastrulation } \\
\text { defects }\end{array}$ & Morpholino targeting hira mRNA & Szenker et al. 2012 & $\begin{array}{l}\text { HIRA KD is viable but leads } \\
\text { to gastrulation defects }\end{array}$ \\
\hline & & & & daxx annotated as DAXX homolog & Lewis et al. 2010 & No mutant alleles tested \\
\hline \multirow[t]{3}{*}{ Mus musculus } & $\begin{array}{l}\text { Insertional mutagenesis by } \\
\text { gene trapping of H3f3a in } \\
\text { 129Sv/Ev background }\end{array}$ & Couldrey et al. 1999 & $\begin{array}{l}\mathrm{H} 3 \mathrm{f} 3 \mathrm{a} \mathrm{KO} \text { results in significant } \\
\text { neonatal lethality }\end{array}$ & $\begin{array}{l}\text { Targeted deletion of Hira gene in } \\
\text { 129Sv, CD1, C57BL6/129Sv } \\
\text { backgrounds }\end{array}$ & Roberts et al. 2002 & HIRA KO is embryonic lethal \\
\hline & $\begin{array}{l}\text { Conditional KO allele of } H 3 f 3 b \\
\text { (floxed exons } 2-4 \text { using } \\
\text { germline deleter Zp3-Cre) in } \\
\text { C57BL/6N background }\end{array}$ & Bush et al. 2013 & $\begin{array}{c}\text { H3f3b KO results in significant } \\
\text { neonatal lethality, females are } \\
\text { subfertile, males are infertile }\end{array}$ & $\begin{array}{l}\text { Targeted deletion of Daxx gene in } \\
129 \mathrm{~Sv} / \mathrm{Ev}, 129 \mathrm{~Sv} / \mathrm{Ev} / \mathrm{BLKSW} \\
\text { backgrounds }\end{array}$ & Michaelson et al. 1999 & $\begin{array}{l}\text { DAXX KO is embryonic } \\
\text { lethal }\end{array}$ \\
\hline & $\begin{array}{l}\text { Conditional KO allele of H3f3a } \\
\text { or H3f3b (floxed exons } 2 \\
\text { using germline deleter Hprt- } \\
\text { Cre) in 129S1/Sv background }\end{array}$ & Tang et al. 2015 & $\begin{array}{l}\mathrm{H} 3 \mathrm{f} 3 \mathrm{a} \mathrm{KO} \text { is viable, males are } \\
\text { subfertile; } \mathrm{H} 3 \mathrm{f} 3 \mathrm{~b} \mathrm{KO} \text { is lethal }\end{array}$ & & & \\
\hline \multirow[t]{2}{*}{ Homo sapiens } & $\begin{array}{l}\text { Mutations } \mathrm{H} 3.3 \mathrm{~K} 27 \mathrm{M} \text { or } \mathrm{H} 3.3 \\
\text { G34R/V in pediatric cancers }\end{array}$ & $\begin{array}{l}\text { Schwartzentruber et al. } \\
\text { 2012; Wu et al. } 2012\end{array}$ & $\begin{array}{l}\text { Glioblastoma multiforme } \\
(\text { GBM })\end{array}$ & $\begin{array}{l}\text { Point mutation (L786M) in } U B N 1 \text { in } \\
\text { consanguineous families }\end{array}$ & Shamseldin et al. 2015 & $\begin{array}{l}\text { HIRA complex subunit } \\
\text { recessive mutant is } \\
\text { embryonic lethal }\end{array}$ \\
\hline & & & $\begin{array}{l}\text { Diffuse intrinsic pontine } \\
\text { glioma (DIPG) }\end{array}$ & $\begin{array}{l}\text { Mutations in pancreatic } \\
\text { neuroendocrine tumors (PanNETs) } \\
\text { and GBM }\end{array}$ & $\begin{array}{l}\text { Jiao et al. 2011; Heaphy } \\
\text { et al. 2011; } \\
\text { Schwartzentruber et al. } \\
2012\end{array}$ & $\begin{array}{l}\text { Mutant DAXX/ATRX } \\
\text { complex is linked to cancer }\end{array}$ \\
\hline
\end{tabular}


single replicative H3 variant-namely H3.2 - enables a simple comparison of the replicative and replacement variant contributions to a given phenotype. Also, both H3.2 and H3.3 protein sequences are conserved between $\mathrm{Xe}$ nopus and human. Finally, the extensive characterization of Xenopus development is a major advantage to analyze phenotypes at distinct developmental transitions (Nieuwkoop and Faber 1994). After fertilization, the embryo starts to divide quickly without any gap phases, whereas no zygotic transcription is detected (Fig. 5A; Dumont 1972; Keller 1991). This time window provides a unique setting to explore the importance of histone variant dynamics independent of any role in transcription. Following this period of rapid embryonic cell cycles, MBT marks

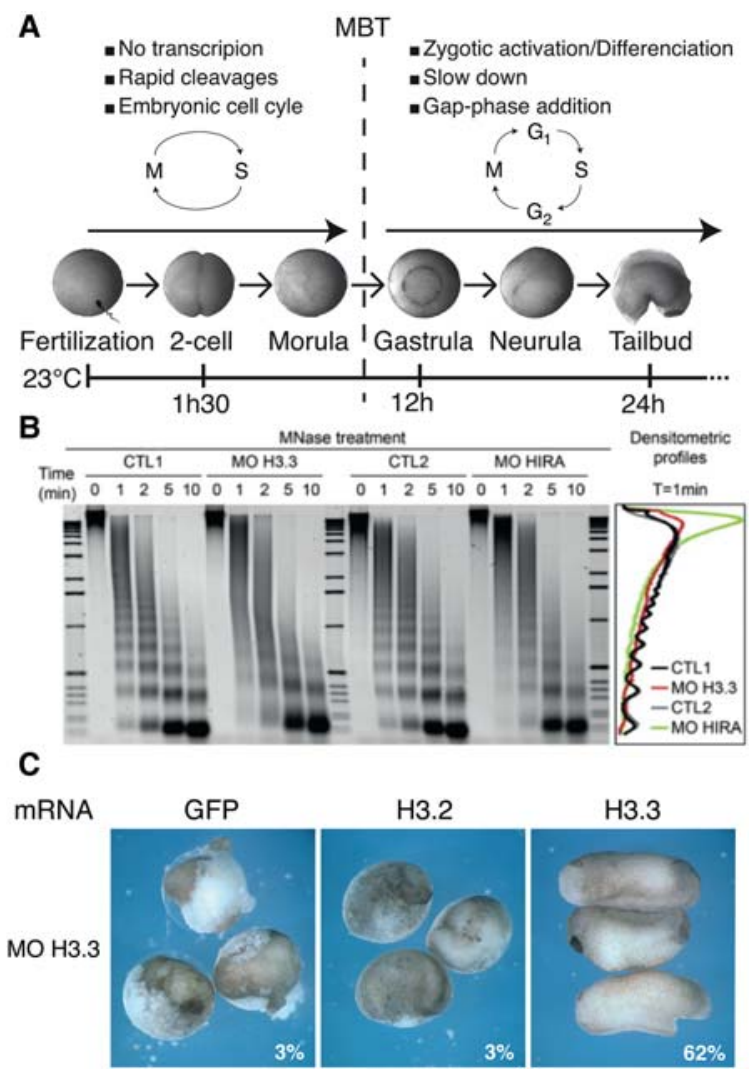

Figure 5. H3.3 plays a nonredundant role in Xenopus early development. (A) Well-characterized Xenopus laevis embryonic development provides a crucial window for studying chromatin. The embryo undergoes rapid synchronous cell divisions without any zygotic transcription until the midblastula transition (MBT). After the MBT, gap phases are introduced in the cell cycle along with the onset of zygotic transcription. (B) Chromatin disorganization upon depletion of a crucial brick (H3.3) or architect (HIRA). MNase digestion profile of H3.3 and HIRA morpholino (MO) injected embryos. Stage 14 embryos were used to prepare nuclei. For each time point of MNase digestion, purified DNA fragments were analyzed by agarose gel electrophoresis. Densitometric profiles of the 1-min digestion products are shown on the right (Szenker et al. 2012). (C) H3.2 expression does not rescue loss of H3.3 during Xenopus early development. H3.3 $\mathrm{MO}$ and indicated mRNAs were injected into two-cell stage embryos. Stage 25 embryos were used for image acquisition. Percentage viability of 30 embryos is shown. (Adapted from Szenker et al. 2012.) the activation of zygotic transcription. At this transition, cell division time slows down, intervening $G_{1}$ and $G_{2}$ phases are incorporated into the cell cycle to match the duration observed in somatic cells (Newport and Kirschner 1982) and cell migration begins.

With this model system, we could explore specific roles for $\mathrm{H} 3$ variants in development and cell fate determination. Following knockdown of endogenous H3.3 or its chaperone HIRA using a morpholino strategy, we found that $\mathrm{Xe}$ nopus embryos developed up to the early gastrula stage but showed severe defects at late gastrulation (Szenker et al. 2012). Consequently, mutant embryos underwent massive apoptosis and did not develop to term. Furthermore, depletion of either H3.3 or HIRA led to chromatin disorganization as attested by MNase digestion (Fig. 5B), and we observed aberrant transcription of gastrulation-specific genes (Szenker et al. 2012). Interestingly, rescue experiments using exogenous H3.2 variant failed to overcome the defects due to H3.3 loss (Fig. 5C). Thus, our findings reveal a critical developmental context wherein $\mathrm{H} 3.3$ exerts an essential, nonredundant function. Similar observations in mouse models corroborate the inability of replicative variants to substitute for the loss of the replacement variant during early development (Couldrey et al. 1999; Bush et al. 2013; Tang et al. 2015). This is in contrast with findings from Tetrahymena thermophila (Cui et al. 2006) and D. melanogaster (Sakai et al. 2009), in which the increased expression of the replicative histone variant can overcome the lack of H3.3 from the histone pool. Considering these discrepancies, we hypothesized that our results may be explained by the restricted ability of certain cognate chaperones to interact with only one histone variant, rather than any intrinsic properties of the incorporated variants. In order to test this hypothesis, rescue experiments conducted in Xenopus offer attractive possibilities to explore combinatorial mutations of distinct chaperonevariant pairs. Using this developmental system, we hope to decipher how the fine-tuned balance between brick quality and quantity and the choice made by a given architect underpin the homeostasis of functional chromatin.

\section{CONCLUSION}

In this review, we highlight two principal mechanisms that influence chromatin architecture and function: (1) dosage fluctuations of individual bricks and architects and (2) context-specific regulation of these factors. The nuclear abundance of most histone variants exceeds the concentration of their cognate histone chaperones. Underlying this stoichiometric disparity, cells maintain a basal equilibrium in the dosage of architects and bricks. We envisage that this principle could apply to wide-ranging events involved in numerous developmental changes and diseases. Nonetheless, future experimental perturbation of this delicate balance between variants and architects, at different loci and times, will help characterize the link to human pathology. In the face of potential disequilibrium, the chaperone-variant circuitry employs adaptive buffering mechanisms during specific cellular contexts. Our work on CENP-A and H3.3 modulation in cancer (Lacoste 
et al. 2014; Filipescu et al. 2017) and development (Szenker et al. 2012), respectively, illustrates a remarkable, in-built contingency plan within the system (Fig. 6).

Experimental overexpression of CENP-A can lead to ectopic deposition in the chromosome arms by the histone chaperone DAXX, instead of HJURP (Fig. 6A). The most critical situation is encountered when tumor cells lack p53 (Fig. 6B). Our model integrates CENP-A deposition by HJURP with the activity of the p53 checkpoint pathway whereby tumors become addicted to the high level of HJURP in the absence of p53. In this scheme, HJURP and CENP-A should be considered as major anticancer targets. A similar scenario likely plays out in several, albeit not all, cancers. Moving toward precision medicine, a perspective on interactions between histones chaperones and the canonical cancer drivers (oncogenes and tumor suppressors) could help identify cases of synthetic lethality and circumvent emergence of drug resistance.

The critical role of $\mathrm{H} 3.3$ variant during gastrulation in the tractable Xenopus development model (Fig. 6C) raises several fundamental and clinical issues. In light of the importance of variant-chaperone balance, it will be interesting to dissect H3.3 functions in the context of its chaperone interactions. It will also be important to address whether intrinsic properties of this specific variant determine its behavior in the chromatin. In the future, characterization of disease-associated mutants will provide insight into pathology of developmental diseases, such as pediatric cancers.

Here, we have shown the importance of chaperone-variant interactions in common cellular and developmental models. Further research will benefit from altering the chaperone--variant balance in other organismal systems, including additional human and mouse models. Extending these findings to other critical players such as Polycomb repressive complexes, regulators of cellular differentiation during development, will play a role in delineating a link with development and disease. Indeed, stem cell differentiation, neurogenesis and immune cell lineage commitment represent promising new directions to harness the insights from the current work on chaperone-variant interactions.

In conclusion, dosage regulation, specific histone variant characteristics, and chaperone choice prove to be integral elements of chromatin regulation. Combined together, these findings raise several unresolved questions: "When" (during cell cycle and development process), "where" (at distinct genomic landmarks and in specific cell types), and "how" (in a dose-dependent manner or under the influence of genotoxic stress such as DNA damage) do vital partner switches occur? Future studies will have to elaborate upon a unifying consideration that now surrounds the critical driving forces for shaping chromatin in the nucleus: is it the means of nucleosome assembly or the choice of histone variant that matters, or both? Ultimately, these properties will inform our understanding of the complex aspects underlying development and disease in different cellular contexts.

\footnotetext{
"All things are poison and nothing is without poison; only the dose makes a thing not a poison" Paracelsus
}

A
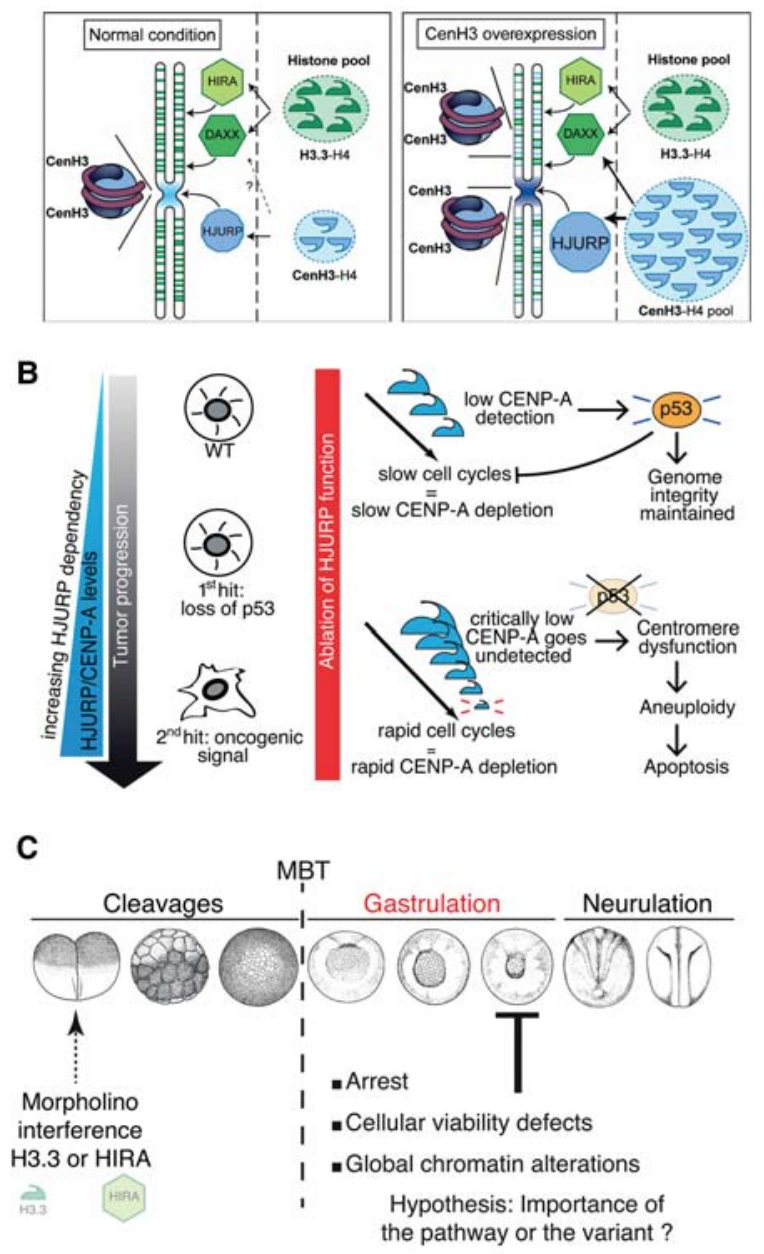

Figure 6. Dosage and context matter: important tenets of chromatin maintenance. $(A)$ Overexpression of cenH3 results in partner switching within the chaperone-variant circuitry (Lacoste et al. 2014). Schematic model of cenH3 overexpression in human cells. In physiological conditions, cenH3-H4 is loaded at the centromere by HJURP. The H3.3-H4 pool is taken care of by DAXX or HIRA for loading in chromosome arms. When the pool of cenH3-H4 increases, HJURP is overexpressed and greater concentration of cenH3 is found at the centromere. The excess of cenH3 is handled by DAXX that loads or maintains it in chromosome arms. (B) Increasing levels of HJURP maintain tumorigenesis in cells lacking functional p53. The model integrates CENP-A deposition by HJURP with the activity of the p53 checkpoint pathway. There are different outcomes, following CENP-A or HJURP knockout, dependent on the p53 status. When cell cycle is slow and CENP-A levels are low in p53proficient cells, genome integrity remains intact and is protected by the function of p53. Tumor growth arrest, due to loss of CENP-A at centromeres, in established p53-deficient tumors is striking and underlines a case of epigenetic-addiction to high levels of HJURP. If HJURP is depleted in this context, it leads to massive aneuploidy and apoptosis. Thus, tumors become addicted to the high level of HJURP in the absence of p53. (C) In Xenopus laevis, selective loss of H3.3 variant causes global chromatin dysregulation during early development (Szenker et al. 2012). Depletion of endogenous H3.3 impairs cellular viability leading to gastrulation defects. Histone chaperone HIRA knockdown gives rise to similar phenotypes, implicating the DNA synthesis-independent H3.3 incorporation pathway during development. ( $A$, Adapted, with permission, from Lacoste et al. 2014; $B$, reprinted, with permission, from Filipescu et al. 2017.) 


\section{ACKNOWLEDGMENTS}

We apologize to all our colleagues whose valuable work in this field was not cited because of space constraints. This work was supported by la Ligue Nationale contre le Cancer (Equipe labellisée Ligue), ANR-11-LABX0044_DEEP and ANR-10-IDEX-0001-02 PSL, ANR12-BS V5-0022-02 “CHAPINHIB," ANR-14-CE160009 "Epicure,” ANR-14-CE10-0013 “CELLECTCHIP,” EU project 678563 "EPOCH28," ERC-2015-ADG694694 "ChromADICT,” ANR-16-CE15-0018 “CHRODYT," ANR-16-CE12-0024 "CHIFT," "Parisian Alliance of Cancer Research Institutes.” D.S. was supported by PSL.

\section{REFERENCES}

Adam S, Polo SE, Almouzni G. 2013. Transcription recovery after DNA damage requires chromatin priming by the H3.3 histone chaperone HIRA. Cell 155: 94-106.

Ahmad K, Henikoff S. 2002. The histone variant H3.3 marks active chromatin by replication-independent nucleosome assembly. Mol Cell 9: 1191-1200.

Allshire RC, Karpen GH. 2008. Epigenetic regulation of centromeric chromatin: Old dogs, new tricks? Nat Rev Genet 9: 923937.

Almouzni G, Mechali M. 1988. Xenopus egg extracts: A model system for chromatin replication. Biochim Biophys Acta 951: $443-450$

Almouzni G, Clark DJ, Mechali M, Wolffe AP. 1990. Chromatin assembly on replicating DNA in vitro. Nucleic Acids Res 18: 5767-5774.

Amato A, Schillaci T, Lentini L, Di Leonardo A. 2009. CENPA overexpression promotes genome instability in $\mathrm{pRb}$-depleted human cells. Mol Cancer 8: 119.

Amodeo AA, Jukam D, Straight AF, Skotheim JM. 2015. Histone titration against the genome sets the DNA-to-cytoplasm threshold for the Xenopus midblastula transition. Proc Natl Acad Sci 112: E1086-E1095.

Banumathy G, Somaiah N, Zhang R, Tang Y, Hoffmann J, Andrake M, Ceulemans H, Schultz D, Marmorstein R, Adams PD. 2009. Human UBN1 is an ortholog of yeast Hpc2p and has an essential role in the HIRA/ASF1a chromatin-remodeling pathway in senescent cells. Mol Cell Biol 29: 758-770.

Barsotti AM, Prives C. 2009. Pro-proliferative FoxM1 is a target of p53-mediated repression. Oncogene 28: 4295-4305.

Benito JM, Godfrey L, Kojima K, Hogdal L, Wunderlich M, Geng H, Marzo I, Harutyunyan KG, Golfman L, North P, et al. 2015. MLL-rearranged acute lymphoblastic leukemias activate BCL-2 through H3K79 methylation and are sensitive to the BCL-2-specific antagonist ABT-199. Cell Rep 13: 2715-2727.

Bieging KT, Mello SS, Attardi LD. 2014. Unravelling mechanisms of p53-mediated tumour suppression. Nat Rev Cancer 14: 359-370.

Bird A. 2007. Perceptions of epigenetics. Nature 447: 396-398.

Bodor DL, Valente LP, Mata JF, Black BE, Jansen LE. 2013. Assembly in G1 phase and long-term stability are unique intrinsic features of CENP-A nucleosomes. Mol Biol Cell 24: 923-932.

Bodor DL, Mata JF, Sergeev M, David AF, Salimian KJ, Panchenko T, Cleveland DW, Black BE, Shah JV, Jansen LE. 2014. The quantitative architecture of centromeric chromatin. Elife 3: 02137.

Bonnefoy E, Orsi GA, Couble P, Loppin B. 2007. The essential role of Drosophila HIRA for de novo assembly of paternal chromatin at fertilization. PLoS Genet 3: 1991-2006.

Bowman GD, Poirier MG. 2014. Post-translational modifications of histones that influence nucleosome dynamics. Chem Rev 115: 2274-2295.
Burglin TR, Mattaj IW, Newmeyer DD, Zeller R, De Robertis EM. 1987. Cloning of nucleoplasmin from Xenopus laevis oocytes and analysis of its developmental expression. Genes Dev 1: 97-107.

Buschbeck M, Hake SB. 2017. Variants of core histones and their roles in cell fate decisions, development and cancer. Nat Rev Mol Cell Biol 18: 299-314.

Bush KM, Yuen BT, Barrilleaux BL, Riggs JW, O’Geen H, Cotterman RF, Knoepfler PS. 2013. Endogenous mammalian histone H3.3 exhibits chromatin-related functions during development. Epigenetics Chromatin 6: 7.

Cheloufi S, Elling U, Hopfgartner B, Jung YL, Murn J, Ninova M, Hubmann M, Badeaux AI, Euong Ang C, Tenen D, et al. 2015. The histone chaperone CAF-1 safeguards somatic cell identity. Nature 528: 218-224.

Clement C, Almouzni G. 2015. MCM2 binding to histones H3H4 and ASF1 supports a tetramer-to-dimer model for histone inheritance at the replication fork. Nat Struct Mol Biol 22: 587-589.

Cook AJ, Gurard-Levin ZA, Vassias I, Almouzni G. 2011. A specific function for the histone chaperone NASP to finetune a reservoir of soluble $\mathrm{H} 3-\mathrm{H} 4$ in the histone supply chain. Mol Cell 44: 918-927.

Corpet A, De Koning L, Toedling J, Savignoni A, Berger F, Lemaitre C, O'Sullivan RJ, Karlseder J, Barillot E, Asselain B, et al. 2011. Asflb, the necessary Asfl isoform for proliferation, is predictive of outcome in breast cancer. EMBO J 30: 480-493.

Couldrey C, Carlton MBL, Nolan PM, Colledge WH, Evans MJ. 1999. A retroviral gene trap insertion into the histone $3.3 \mathrm{~A}$ gene causes partial neonatal lethality, stunted growth, neuromuscular deficits and male sub-fertility in transgenic mice. Hum Mol Genet 8: 2489-2495.

Cui B, Liu Y, Gorovsky MA. 2006. Deposition and function of histone H3 variants in Tetrahymena thermophila. Mol Cell Biol 26: 7719-7730.

De Koning L, Corpet A, Haber JE, Almouzni G. 2007. Histone chaperones: An escort network regulating histone traffic. Nat Struct Mol Biol 14: 997-1007.

Dion MF, Kaplan T, Kim M, Buratowski S, Friedman N, Rando OJ. 2007. Dynamics of replication-independent histone turnover in budding yeast. Science 315: 1405-1408.

Drane P, Ouararhni K, Depaux A, Shuaib M, Hamiche A. 2010. The death-associated protein DAXX is a novel histone chaperone involved in the replication-independent deposition of H3.3. Genes Dev 24: 1253-1265.

Duc C, Benoit M, Le Goff S, Simon L, Poulet A, Cotterell S, Tatout C, Probst AV. 2015. The histone chaperone complex HIR maintains nucleosome occupancy and counterbalances impaired histone deposition in CAF-1 complex mutants. Plant J 81: 707-722.

Dumont JN. 1972. Oogenesis in Xenopus laevis (Daudin). I. Stages of oocyte development in laboratory maintained animals. J Morphol 136: 153-179.

Dunleavy EM, Roche D, Tagami H, Lacoste N, Ray-GalletD, Nakamura Y, Daigo Y, Nakatani Y, Almouzni-Pettinotti G. 2009. HJURP is a cell-cycle-dependent maintenance and deposition factor of CENP-A at centromeres. Cell 137: 485-497.

Earnshaw WC, Rothfield N. 1985. Identification of a family of human centromere proteins using autoimmune sera from patients with scleroderma. Chromosoma 91: 313-321.

Filipescu D, Naughtin M, Podsypanina K, Lejour V, Wilson L, Gurard-Levin ZA, Orsi GA, Simeonova I, Toufektchan E, Attardi LD, et al. 2017. Essential role for centromeric factors following p53 loss and oncogenic transformation. Genes Dev 31: $463-480$.

Finn RM, Ellard K, Eirin-Lopez JM, Ausio J. 2012. Vertebrate nucleoplasmin and NASP: Egg histone storage proteins with multiple chaperone activities. FASEB J 26: 4788-4804.

Foltz DR, Jansen LE, Bailey AO, Yates JR III, Bassett EA, Wood S, Black BE, Cleveland DW. 2009. Centromere-specific assembly of CENP-A nucleosomes is mediated by HJURP. Cell 137: $472-484$. 
Franklin SG, Zweidler A. 1977. Non-allelic variant of histone 2a, $2 \mathrm{~b}$ and 3 in mammals. Nature 266: 273-275.

Fromental-Ramain C, Ramain P, Hamiche A. 2017. The Drosophila DAXX-like protein (DLP) cooperates with ASF1 for H3.3 deposition and heterochromatin formation. Mol Cell Biol 37: e00597-16.

Fukagawa T, Earnshaw WC. 2014. The centromere: Chromatin foundation for the kinetochore machinery. Dev Cell 30: 496508.

Gaillard PH, Martini EM, Kaufman PD, Stillman B, Moustacchi E, Almouzni G. 1996. Chromatin assembly coupled to DNA repair: A new role for chromatin assembly factor I. Cell 86: 887-896.

Gibbons RJ, Picketts DJ, Villard L, Higgs DR. 1995. Mutations in a putative global transcriptional regulator cause X-linked mental retardation with $\alpha$-thalassemia (ATR-X syndrome). Cell 80: 837-845.

Goldberg AD, Banaszynski LA, Noh KM, Lewis PW, Elsaesser SJ, Stadler S, Dewell S, Law M, Guo X, Li X, et al. 2010. Distinct factors control histone variant H3.3 localization at specific genomic regions. Cell 140: 678-691.

Gossett AJ, Lieb JD. 2012. In vivo effects of histone H3 depletion on nucleosome occupancy and position in Saccharomyces cerevisiae. PLoS Genet 8: e1002771.

Groth A, Ray-Gallet D, Quivy JP, Lukas J, Bartek J, Almouzni G. 2005. Human Asfl regulates the flow of $\mathrm{S}$ phase histones during replicational stress. Mol Cell 17: 301-311.

Groth A, Corpet A, Cook AJ, Roche D, Bartek J, Lukas J, Almouzni G. 2007. Regulation of replication fork progression through histone supply and demand. Science 318: 1928 1931.

Gu XM, Fu J, Feng XJ, Huang X, Wang SM, Chen XF, Zhu MH, Zhang SH. 2014. Expression and prognostic relevance of centromere protein A in primary osteosarcoma. Pathol Res Pract 210: 228-233.

Gurard-Levin ZA, Almouzni G. 2014. Histone modifications and a choice of variant: A language that helps the genome express itself. F1000Prime Rep 6: 76.

Gurard-Levin ZA, Quivy JP, Almouzni G. 2014. Histone chaperones: Assisting histone traffic and nucleosome dynamics. Annu Rev Biochem 83: 487-517.

Gurard-Levin ZA, Wilson LO, Pancaldi V, Postel-Vinay S, Sousa FG, Reyes C, Marangoni E, Gentien D, Valencia A, Pommier Y, et al. 2016. Chromatin regulators as a guide for cancer treatment choice. Mol Cancer Ther 15: 1768-1777.

Gurdon JB. 1962. The developmental capacity of nuclei taken from intestinal epithelium cells of feeding tadpoles. J Embryol Exp Morphol 10: 622-640.

Gurdon JB. 1976. Injected nuclei in frog oocytes-Fate, enlargement, and chromatin dispersal. J Embryol Exp Morphol 36: 523-540.

Hammond CM, Stromme CB, Huang H, Patel DJ, Groth A. 2017. Histone chaperone networks shaping chromatin function. Nat Rev Mol Cell Biol 18: 141-158.

Heaphy CM, de Wilde RF, Jiao Y, Klein AP, Edil BH, Shi C, Bettegowda C, Rodriguez FJ, Eberhart CG, Hebbar S, et al. 2011. Altered telomeres in tumors with ATRX and DAXX mutations. Science 333: 425.

Heo JI, Cho JH, Kim JR. 2013. HJURP regulates cellular senescence in human fibroblasts and endothelial cells via a p53-dependent pathway. J Gerontol A Biol Sci Med Sci 68: 914-925.

Hodl M, Basler K. 2009. Transcription in the absence of histone H3.3. Curr Biol 19: 1221-1226.

Houlard M, Berlivet S, Probst AV, Quivy JP, Hery P, Almouzni G, Gerard M. 2006. CAF-1 is essential for heterochromatin organization in pluripotent embryonic cells. PLoS Genet 2: e181.

Huang H, Stromme CB, Saredi G, Hodl M, Strandsby A, Gonzalez-Aguilera C, Chen S, Groth A, Patel DJ. 2015. A unique binding mode enables MCM2 to chaperone histones H3-H4 at replication forks. Nat Struct Mol Biol 22: 618-626.

Ishiuchi T, Enriquez-Gasca R, Mizutani E, Boskovic A, ZieglerBirling C, Rodriguez-Terrones D, Wakayama T, Vaquerizas
JM, Torres-Padilla ME. 2015. Early embryonic-like cells are induced by downregulating replication-dependent chromatin assembly. Nat Struct Mol Biol 22: 662-671.

Jacob Y, Bergamin E, Donoghue MT, Mongeon V, LeBlanc C, Voigt P, Underwood CJ, Brunzelle JS, Michaels SD, Reinberg D, et al. 2014. Selective methylation of histone H3 variant H3.1 regulates heterochromatin replication. Science 343: $1249-1253$.

Jamai A, Imoberdorf RM, Strubin M. 2007. Continuous histone $\mathrm{H} 2 \mathrm{~B}$ and transcription-dependent histone $\mathrm{H} 3$ exchange in yeast cells outside of replication. Mol Cell 25: 345-355.

Jansen LE, Black BE, Foltz DR, Cleveland DW. 2007. Propagation of centromeric chromatin requires exit from mitosis. $J$ Cell Biol 176: 795-805.

Jiang D, Berger F. 2017. DNA replication-coupled histone modification maintains Polycomb gene silencing in plants. Science 357: 1146-1149.

Jiao Y, Shi C, Edil BH, de Wilde RF, Klimstra DS, Maitra A, Schulick RD, Tang LH, Wolfgang CL, Choti MA, et al. 2011. DAXX/ATRX, MEN1, and mTOR pathway genes are frequently altered in pancreatic neuroendocrine tumors. Science 331: 1199-1203.

Jullien J, Astrand C, Szenker E, Garrett N, Almouzni G, Gurdon JB. 2012. HIRA dependent H3.3 deposition is required for transcriptional reprogramming following nuclear transfer to Xenopus oocytes. Epigenetics Chromatin 5: 17.

Katagiri C, Ohsumi K. 1994. Remodeling of sperm chromatin induced in egg extracts of amphibians. Int J Dev Biol 38: 209216.

Kato T, Sato N, Hayama S, Yamabuki T, Ito T, Miyamoto M, Kondo S, Nakamura Y, Daigo Y. 2007. Activation of Holliday junction recognizing protein involved in the chromosomal stability and immortality of cancer cells. Cancer Res 67: 8544-8553.

Kaufman PD, Cohen JL, Osley MA. 1998. Hir proteins are required for position-dependent gene silencing in Saccharomyces cerevisiae in the absence of chromatin assembly factor I. Mol Cell Biol 18:8 4793-4806.

Keller R. 1991. Early embryonic development of Xenopus laevis. Methods Cell Biol 36: 61-113.

Kornberg RD. 1974. Chromatin structure: A repeating unit of histones and DNA. Science 184: 868-871.

Lacoste N, Woolfe A, Tachiwana H, Villar Garea A, Barth T, Cantaloube S, Kurumizaka H, Imhof A, Almouzni G. 2014. Mislocalization of the centromeric histone variant CenH3/ CENP-A in human cells depends on the chaperone DAXX. Mol Cell 53: 631-644.

Lamour V, Lécluse Y, Desmaze C, Spector M, Bodescot M, Aurias A, Osley MA, Lipinski M. 1995. A human homolog of the $S$. cerevisiae HIR1 and HIR2 transcriptional repressors cloned from the DiGeorge syndrome critical region. Hum Mol Genet 4: 791-799.

Laskey RA, Mills AD, Morris NR. 1977. Assembly of SV40 chromatin in a cell-free system from Xenopus eggs. Cell 10: 237-243.

Laskey RA, Honda BM, Mills AD, Finch JT. 1978. Nucleosomes are assembled by an acidic protein which binds histones and transfers them to DNA. Nature 275: 416-420.

Lewis PW, Elsaesser SJ, Noh KM, Stadler SC, Allis CD. 2010. Daxx is an H3.3-specific histone chaperone and cooperates with ATRX in replication-independent chromatin assembly at telomeres. Proc Natl Acad Sci 107: 14075-14080.

Lewis PW, Muller MM, Koletsky MS, Cordero F, Lin S, Banaszynski LA, Garcia BA, Muir TW, Becher OJ, Allis CD. 2013. Inhibition of PRC2 activity by a gain-of-function H3 mutation found in pediatric glioblastoma. Science 340: $857-861$

Li Y, Zhu Z, Zhang S, Yu D, Yu H, Liu L, Cao X, Wang L, Gao H, Zhu M. 2011. ShRNA-targeted centromere protein A inhibits hepatocellular carcinoma growth. PLoS One 6: e17794.

Litvin J, King ML. 1988. Expression and segregation of nucleoplasmin during development in Xenopus. Development 102: $9-21$. 
Loppin B, Bonnefoy E, Anselme C, Laurencon A, Karr TL, Couble P. 2005. The histone H3.3 chaperone HIRA is essential for chromatin assembly in the male pronucleus. Nature 437: 1386-1390.

Loyola A, Bonaldi T, Roche D, Imhof A, Almouzni G. 2006. PTMs on $\mathrm{H} 3$ variants before chromatin assembly potentiate their final epigenetic state. Mol Cell 24: 309-316.

Luger K, Mäder AW, Richmond RK, Sargent DF, Richmond TJ. 1997. Crystal structure of the nucleosome core particle at $2.8 \AA$ resolution. Nature 389: 251-560.

Ma XJ, Salunga R, Tuggle JT, Gaudet J, Enright E, McQuary P, Payette T, Pistone M, Stecker K, Zhang BM, et al. 2003. Gene expression profiles of human breast cancer progression. Proc Natl Acad Sci 100: 5974-5979.

MacAlpine DM, Almouzni G. 2013. Chromatin and DNA replication. Cold Spring Harb Perspect Biol 5: a010207.

Maehara K, Takahashi K, Saitoh S. 2010. CENP-A reduction induces a $\mathrm{p} 53$-dependent cellular senescence response to protect cells from executing defective mitoses. Mol Cell Biol 30: 2090-2104.

Maze I, Noh KM, Soshnev AA, Allis CD. 2014. Every amino acid matters: Essential contributions of histone variants to mammalian development and disease. Nat Rev Genet 15: 259-271.

McGhee JD, Felsenfeld G. 1980. Nucleosome structure. Annu Rev Biochem 49: 1115-1156.

McKinley KL, Cheeseman IM. 2016. The molecular basis for centromere identity and function. Nat Rev Mol Cell Biol 17: $16-29$.

Mello JA, Silljé HHW, Roche D, Kirschner DB, Nigg EA, Almouzni G. 2002. Human Asf1 and CAF-1 interact and synergize in a repair-coupled nucleosome assembly pathway. EMBO Rep 3: 329-334.

Miao W, Xiong J, Bowen J, Wang W, Liu Y, Braguinets O, Grigull J, Pearlman RE, Orias E, Gorovsky MA. 2009. Microarray analyses of gene expression during the Tetrahymena thermophila life cycle. PLoS One 4: e4429.

Michaelson JS, Bader D, Kuo F, Kozak C, Leder P. 1999. Loss of Daxx, a promiscuously interacting protein, results in extensive apoptosis in early mouse development. Genes Dev 13: 1918 1923.

Montes de Oca R, Gurard-Levin ZA, Berger F, Rehman H, Martel E, Corpet A, de Koning L, Vassias I, Wilson LO, Meseure D, et al. 2015. The histone chaperone HJURP is a new independent prognostic marker for luminal A breast carcinoma. Mol Oncol 9: 657-674.

Morel D, Almouzni G, Soria JC, Postel-Vinay S. 2017. Targeting chromatin defects in selected solid tumors based on oncogene addiction, synthetic lethality and epigenetic antagonism. Ann Oncol 28: 254-269.

Muller S, Almouzni G. 2017. Chromatin dynamics during the cell cycle at centromeres. Nat Rev Genet 18: 192-208.

Munakata T, Adachi N, Yokoyama N, Kuzuhara T, Horikoshi M. 2000. A human homologue of yeast anti-silencing factor has histone chaperone activity. Genes Cells 5: 221-233.

Naumova N, Imakaev M, Fudenberg G, Zhan Y, Lajoie BR, Mirny LA, Dekker J. 2013. Organization of the mitotic chromosome. Science 342: 948-953.

Nechemia-Arbely Y, Fachinetti D, Miga KH, Sekulic N, Soni GV, Kim DH, Wong AK, Lee AY, Nguyen K, Dekker C, et al. 2017. Human centromeric CENP-A chromatin is a homotypic, octameric nucleosome at all cell cycle points. $J$ Cell Biol 216: 607-621.

Newport J, Kirschner M. 1982. A major developmental transition in early Xenopus embryos: I. Characterization and timing of cellular changes at the midblastula stage. Cell 30: 675-686.

$\mathrm{Ng}$ RK, Gurdon JB. 2008. Epigenetic memory of an active gene state depends on histone H3.3 incorporation into chromatin in the absence of transcription. Nat Cell Biol 10: 102-109.

Nieuwkoop PD, Faber J, eds. 1994. Normal table of Xenopus laevis (Daudin): A systematic and chronological survey of the development from the fertilized egg till the end of metamorphosis. Garland, New York.
Nora EP, Lajoie BR, Schulz EG, Giorgetti L, Okamoto I, Servant N, Piolot T, van Berkum NL, Meisig J, Sedat J, et al. 2012. Spatial partitioning of the regulatory landscape of the $\mathrm{X}$-inactivation centre. Nature 485: 381-385.

Olins AD, Olins DE. 1974. Spheroid chromatin units (v bodies). Science 183: 330-333.

Orsi GA, Algazeery A, Meyer RE, Capri M, Sapey-Triomphe LM, Horard B, Gruffat H, Couble P, Ait-Ahmed O, Loppin B. 2013. Drosophila yemanuclein and HIRA cooperate for de novo assembly of H3.3-containing nucleosomes in the male pronucleus. PLoS Genet 9: e1003285.

Osley MA. 1991. The regulation of histone synthesis in the cell cycle. Annu Rev Biochem 60: 827-861.

O'Sullivan RJ, Almouzni G. 2014. Assembly of telomeric chromatin to create ALTernative endings. Trends Cell Biol 24: 675 685.

Oudet P, Gross-Bellard M, Chambon P. 1975. Electron microscopic and biochemical evidence that chromatin structure is a repeating unit. Cell 4: 281-300.

Palmer DK, O’Day K, Trong HL, Charbonneau H, Margolis RL. 1991. Purification of the centromere-specific protein CENP-A and demonstration that it is a distinctive histone. Proc Natl Acad Sci 88: 3734-3738.

Piazzesi A, Papić D, Bertan F, Salomoni P, Nicotera P, Bano D. 2016. Replication-independent histone variant H3.3 controls animal lifespan through the regulation of pro-longevity transcriptional programs. Cell Rep 17: 987-996.

Polo SE, Roche D, Almouzni G. 2006. New histone incorporation marks sites of UV repair in human cells. Cell 127: 481493.

Probst AV, Dunleavy E, Almouzni G. 2009. Epigenetic inheritance during the cell cycle. Nat Rev Mol Cell Biol 10: 192-206.

Qian Z, Huang H, Hong JY, Burck CL, Johnston SD, Berman J, Carol A, Liebman SW. 1998. Yeast Ty1 retrotransposition is stimulated by a synergistic interaction between mutations in chromatin assembly factor I and histone regulatory proteins. Mol Cell Biol 18: 4783-4792.

Qiu JJ, Guo JJ, Lv TJ, Jin HY, Ding JX, Feng WW, Zhang Y, Hua KQ. 2013. Prognostic value of centromere protein-A expression in patients with epithelial ovarian cancer. Tumour Biol 34: 2971-2975.

Quivy JP, Grandi P, Almouzni G. 2001. Dimerization of the largest subunit of chromatin assembly factor 1-Importance in vitro and during Xenopus early development. EMBO J 20: 2015-2027.

Ray-Gallet D, Quivy JP, Scamps C, Martini EM, Lipinski M, Almouzni G. 2002. HIRA is critical for a nucleosome assembly pathway independent of DNA synthesis. Mol Cell 9: 1091-1100.

Ray-Gallet D, Woolfe A, Vassias I, Pellentz C, Lacoste N, Puri A, Schultz DC, Pchelintsev NA, Adams PD, Jansen LE, et al. 2011. Dynamics of histone H3 deposition in vivo reveal a nucleosome gap-filling mechanism for H3.3 to maintain chromatin integrity. Mol Cell 44: 928-941.

Richardson RT, Batova IN, Widgren EE, Zheng LX, Whitfield M, Marzluff WF, O'Rand MG. 2000. Characterization of the histone H1-binding protein, NASP, as a cell cycle-regulated somatic protein. $J$ Biol Chem 275: 30378-30386.

Richet N, Liu D, Legrand P, Velours C, Corpet A, Gaubert A, Bakail M, Moal-Raisin G, Guerois R, Compper C, et al. 2015. Structural insight into how the human helicase subunit MCM2 may act as a histone chaperone together with ASF1 at the replication fork. Nucleic Acids Res 43: 1905-1917.

Ricketts MD, Marmorstein R. 2017. A molecular prospective for HIRA complex assembly and H3.3-specific histone chaperone function. J Mol Biol 429: 1924-1933.

Ricketts DM, Frederick B, Hoff H, Tang Y, Schultz DC, Singh Rai T, Grazia Vizioli M, Adams PD, Marmorstein R. 2015. Ubinuclein-1 confers histone H3.3-specific-binding by the HIRA histone chaperone complex. Nat Commun 6: 7711.

Roberts C, Sutherland HF, Farmer H, Kimber W, Halford S, Carey A, Brickman JM, Wynshaw-Boris A, Scambler PJ. 2002. Targeted mutagenesis of the Hira gene results in gastru- 
lation defects and patterning abnormalities of mesoendodermal derivatives prior to early embryonic lethality. Mol Cell Biol 22: 2318-2328.

Rufiange A, Jacques PE, Bhat W, Robert F, Nourani A. 2007. Genome-wide replication-independent histone $\mathrm{H} 3$ exchange occurs predominantly at promoters and implicates H3 K56 acetylation and Asfl. Mol Cell 27: 393-405.

Sakai A, Schwartz BE, Goldstein S, Ahmad K. 2009. Transcriptional and developmental functions of the $\mathrm{H} 3.3$ histone variant in Drosophila. Curr Biol 19: 1816-1820.

Santenard A, Ziegler-Birling C, Koch M, Tora L, Bannister AJ, Torres-Padilla ME. 2010. Heterochromatin formation in the mouse embryo requires critical residues of the histone variant H3.3. Nat Cell Biol 12: 853-862.

Schwartz BE, Ahmad K. 2005. Transcriptional activation triggers deposition and removal of the histone variant H3.3. Genes Dev 19: $804-814$

Schwartzentruber J, Korshunov A, Liu XY, Jones DT, Pfaff E, Jacob K, Sturm D, Fontebasso AM, Quang DA, Tonjes M, et al. 2012. Driver mutations in histone H3.3 and chromatin remodelling genes in paediatric glioblastoma. Nature 482: 226-231.

Shamseldin HE, Tulbah M, Kurdi W, Nemer M, Alsahan N, Al Mardawi E, Khalifa O, Hashem A, Kurdi A, Babay Z, et al. 2015. Identification of embryonic lethal genes in humans by autozygosity mapping and exome sequencing in consanguineous families. Genome Biol 16: 116.

Sharp JA, Fouts ET, Krawitz DC, Kaufman PD. 2001. Yeast histone deposition protein Asflp requires Hir proteins and PCNA for heterochromatic silencing. Curr Biol 11: 463-473.

Shelby RD, Monier K, Sullivan KF. 2000. Chromatin assembly at kinetochores is uncoupled from DNA replication. J Cell Biol 151: 1113-1118.

Shrestha RL, Ahn GS, Staples MI, Sathyan KM, Karpova TS, Foltz DR, Basrai MA. 2017. Mislocalization of centromeric histone $\mathrm{H} 3$ variant CENP-A contributes to chromosomal instability (CIN) in human cells. Oncotarget 8: 46781-46800.

Shuaib M, Ouararhni K, Dimitrov S, Hamiche A. 2010. HJURP binds CENP-A via a highly conserved N-terminal domain and mediates its deposition at centromeres. Proc Natl Acad Sci 107: 1349-1354.

Smith S, Stillman B. 1989. Purification and characterization of CAF-I, a human cell factor required for chromatin assembly during DNA replication in vitro. Cell 58: 15-25.

Stillman B. 1986. Chromatin assembly during SV40 DNA replication in vitro. Cell 45: 555-565.

Sun X, Clermont PL, Jiao W, Helgason CD, Gout PW, Wang Y, Qu S. 2016. Elevated expression of the centromere protein-A (CENP-A)-encoding gene as a prognostic and predictive biomarker in human cancers. Int J Cancer 139: 899-907.

Swygert SG, Peterson CL. 2014. Chromatin dynamics: Interplay between remodeling enzymes and histone modifications. Biochim Biophys Acta 1839: 728-736.

Szenker E, Lacoste N, Almouzni G. 2012. A developmental requirement for HIRA-dependent $\mathrm{H} 3.3$ deposition revealed at gastrulation in Xenopus. Cell Rep 1: 730-740.

Tagami H, Ray-Gallet D, Almouzni G, Nakatani Y. 2004. Histone $\mathrm{H} 3.1$ and H3.3 complexes mediate nucleosome assembly pathways dependent or independent of DNA synthesis. Cell 116: 51-61.

Takahashi K, Yamanaka S. 2006. Induction of pluripotent stem cells from mouse embryonic and adult fibroblast cultures by defined factors. Cell 126: 663-676.
Talbert PB, Henikoff S. 2017. Histone variants on the move: Substrates for chromatin dynamics. Nat Rev Mol Cell Biol 18: $115-126$.

Tang MC, Jacobs SA, Mattiske DM, Soh YM, Graham AN, Tran A, Lim SL, Hudson DF, Kalitsis P, O’Bryan MK, et al. 2015. Contribution of the two genes encoding histone variant H3.3 to viability and fertility in mice. PLoS Genet 11: e1004964.

Tomonaga T, Matsushita K, Yamaguchi S, Oohashi T, Shimada H, Ochiai T, Yoda K, Nomura F. 2003. Overexpression and mistargeting of centromere protein-A in human primary colorectal cancer. Cancer Res 63: 3511-3516.

Torres-Padilla ME, Bannister AJ, Hurd PJ, Kouzarides T, Zernicka-Goetz M. 2006. Dynamic distribution of the replacement histone variant $\mathrm{H} 3.3$ in the mouse oocyte and preimplantation embryos. Int J Dev Biol 50: 455-461.

Tyler JK, Adams CR, Chen SR, Kobayashi R, Kamakaka RT, Kadonaga JT. 1999. The RCAF complex mediates chromatin assembly during DNA replication and repair. Nature 402: 555-560.

Valente V, Serafim RB, de Oliveira LC, Adorni FS, Torrieri R, Tirapelli DP, Espreafico EM, Oba-Shinjo SM, Marie SK, PacoLarson ML, et al. 2013. Modulation of HJURP (Holliday Junction-Recognizing Protein) levels is correlated with glioblastoma cells survival. PLoS One 8: e62200.

Waddington CH. 1957. The strategy of the genes: A discussion of some aspects of theoretical biology. Routledge, Taylor \& Francis Group, (CAllen and Unwin, New York.

Waterborg JH. 2012. Evolution of histone H3: Emergence of variants and conservation of post-translational modification sites. Biochem Cell Biol 90: 79-95.

Welch JE, Zimmerman LJ, Joseph DR, O’Rand MG. 1990. Characterization of a sperm-specific nuclear autoantigenic protein. I. Complete sequence and homology with the Xenopus protein, N1/N2. Biol Reprod 43: 559-568.

Wilming LG, Snoeren CAS, van Rijswijk A, Grosveld F, Meijers C. 1997. The murine homologue of HIRA, a DiGeorge syndrome candidate gene, is expressed in embryonic structures affected in CATCH22 patients. Hum Mol Genet 6: 247-258.

Wollmann H, Holec S, Alden K, Clarke ND, Jacques PE, Berger F. 2012. Dynamic deposition of histone variant H3.3 accompanies developmental remodeling of the Arabidopsis transcriptome. PLoS Genet 8: e1002658.

Wollmann H, Stroud H, Yelagandula R, Tarutani Y, Jiang D, Jing L, Jamge B, Takeuchi H, Holec S, Nie X, et al. 2017. The histone $\mathrm{H} 3$ variant $\mathrm{H} 3.3$ regulates gene body DNA methylation in Arabidopsis thaliana. Genome Biol 18: 94.

Wu G, Broniscer A, McEachron TA, Lu C, Paugh BS, Becksfort J, Qu C, Ding L, Huether R, Parker M, et al. 2012. Somatic histone $\mathrm{H} 3$ alterations in pediatric diffuse intrinsic pontine gliomas and non-brainstem glioblastomas. Nat Genet 44: 251-253.

Yang X, Khosravi-Far R, Chang HY, Baltimore D. 1997. Daxx, a novel Fas-binding protein that activates JNK and apoptosis. Cell 89: 1067-1076.

Yang BX, El Farran CA, Guo HC, Yu T, Fang HT, Wang HF, Schlesinger S, Seah YF, Goh GY, Neo SP, et al. 2015. Systematic identification of factors for provirus silencing in embryonic stem cells. Cell 163: 230-245.

Zhu J, Sammons MA, Donahue G, Dou Z, Vedadi M, Getlik M, Barsyte-Lovejoy D, Al-awar R, Katona BW, Shilatifard A, et al. 2015. Gain-of-function p53 mutants co-opt chromatin pathways to drive cancer growth. Nature 525: 206-211. 


\section{$\$_{\text {CSH }}^{\infty}$ Cold Spring Harbor Symposia SYMPOSIA On Quantitative Biology}

\section{Shaping Chromatin in the Nucleus: The Bricks and the Architects}

David Sitbon, Katrina Podsypanina, Tejas Yadav, et al.

Cold Spring Harb Symp Quant Biol 2017 82: 1-14 originally published online December 5, 2017 Access the most recent version at doi:10.1101/sqb.2017.82.033753

References This article cites 148 articles, 39 of which can be accessed free at: http://symposium.cshlp.org/content/82/1.full.html\#ref-list-1

Creative This article is distributed under the terms of the

Commons http://creativecommons.org/licenses/by-nc/4.0/, which permits reuse and License redistribution, except for commercial purposes, provided that the original author and source are credited.

Email Alerting Receive free email alerts when new articles cite this article - sign up in Service the box at the top right corner of the article or click here. 